\title{
The Transnational Law Market, Regulatory Competition, and Transnational Corporations
}

Horst Eidenmuller

Ludwig-Maximilians-University, Munich, Germany

Follow this and additional works at: https://www.repository.law.indiana.edu/ijgls

Part of the Business Organizations Law Commons, International Law Commons, and the Transnational Law Commons

\section{Recommended Citation}

Eidenmuller, Horst (2011) "The Transnational Law Market, Regulatory Competition, and Transnational Corporations," Indiana Journal of Global Legal Studies: Vol. 18 : Iss. 2 , Article 5.

Available at: https://www.repository.law.indiana.edu/ijgls/vol18/iss2/5

This Symposium is brought to you for free and open access by the Law School Journals at Digital Repository @ Maurer Law. It has been accepted for inclusion in Indiana Journal of Global Legal Studies by an authorized editor of Digital Repository @ Maurer Law. For more information, please contact rvaughan@indiana.edu.

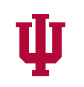

JEROME HALL LAW LIBRARY

INDIANA UNIVERSITY

Maurer School of Law
Blooming ton 


\title{
The Transnational Law Market, Regulatory Competition, and Transnational Corporations
}

\author{
HORST EIDENMÜLLER*
}

\begin{abstract}
In many regions of the world and across various fields, law has become a product. Individuals and companies seek attractive legal regulations, and countries advertise their legal wares globally as they compete for customers. Transnational corporations in particular are prominent actors in the emerging transnational law market. This article investigates the causes of this development and discusses these changes with respect to company law, contract law, the law of dispute resolution, and insolvency law. It assesses the market for legal rules and its practical consequences, and it provides legal policy recommendations for an efficient framework of the transnational law market. The emphasis is on transnational corporations as market actors and on specifics of the European regulatory framework.
\end{abstract}

\section{COMPETITION FOR LAW AS A PRODUCT}

Competition in markets for goods and services is a central feature of market economy systems. The market decides which products and services are offered and at what prices. The boundaries of the market depend on society's decision as to what constitute tradable goods. On its face, law does not appear to belong in this category. We perceive law to be a framework within which trade takes place. We do not, however, consider law itself to be a product.

Nevertheless, law has become a commodity in many parts of the world and in relation to many different topics. Individuals and

* This article is a revised version of a paper that I presented at the "Transnationalism in Law, the State, and Society" Conference held from March 3-5, 2010, in Bremen. Professor, Ludwig-Maximilians-University, Munich, Germany, and Oxford University, Oxford, and Visiting Professor at Harvard Law School in 2011. Habilitation, 1998, Munich; Dr. iur., 1994, Munich; LL.M., 1989, Cambridge. I would like to thank Markus Reps, LL.M. (Wisconsin) for excellent research assistance.

Indiana Journal of Global Legal Studies Vol. 18 \#2 (Summer 2011) (C) Indiana University Maurer School of Law 
companies seek attractive legal regulations, and countries compete for customers of their legal wares. For example, an Italian entrepreneur residing in Bremen could set up an English limited company for her business, finance the enterprise with bonds and loans under New York law, choose arbitration in Switzerland for all disputes that arise, and, should she find herself ruined by her creditor's claims, file for private bankruptcy in France. All of this may be organized from a villa in Bremen with the aim of gaining maximum financial and strategic advantage.

Jurisdictions advertise their legal products and react sensitively to changes in demand. If the statutes of a country do well in business, the tax-paying legal services industry does well too. For this reason, the English Law Society has published a brochure entitled "England and Wales: the jurisdiction of choice." 1 The alleged advantages of English law are described in glowing terms. In his foreword, then-English Secretary of State for Justice Jack Straw writes, "This brochure sets out the reasons for our success and lets people know why it is in their own interests to use English law and to settle their disputes here."2 The professional representatives of legal professionals in Germany could not let this go unanswered. They countered with the brochure "Law made in Germany." In her foreword, then-Minister of Justice Brigitte Zypries says, "Law made in Germany is a guarantee for success." 4 The character of law as a commodity can hardly be expressed more clearly.

This article analyzes important aspects of the law market. It is a market for legal rules, not a market for investments. ${ }^{5}$ This article initially investigates the reasons for the emergence of the law market and continues to illustrate this market with findings in the fields of company law, contract law, the law of dispute resolution, and insolvency law. It highlights the role of transnational corporations as important market actors. Particularly, the normative analysis of the law market and its consequences are of great importance. Based on considerations of economic efficiency, this article develops policy recommendations for the structure of the European legal framework.

1. The Law Soc'y of ENG. \& Wales, England and Wales: The JuRisdiction of CHOICE, available at http://www.lawsociety.org.uk/documents/downloads/jurisdiction _of_choice_brochure.pdf (last visited Feb. 23, 2011).

2. Id. at 5 .

3. BUNDESMINISTERIN DER JUSTIZ, LAW - MADE IN GERMANY, http://www.bmj.bund. de/files/-/3426/Broschuere-Rechtsexport.pdf (last visited Mar. 6, 2011). See also Volker Triebel, Der Kampf ums anwendbare Recht, 5 ANWALTSBLATT 305, 305-08 (2008) (discussing the beginnings of this debate).

4. Id.

5. As to competition for investments, see generally Ehud Kamar, Beyond Competition for Incorporations, 94 GEO. L.J. 1725 (2005). 
This article's focus on the aforementioned fields of law does not mean that the law market is restricted to these areas. Similar developments can also be observed in the law of property and family law. ${ }^{6}$ However, for the purposes of illustration and identification of the decisive structural issues and problems of "law as a product," concentration on the areas selected here is sufficient. The same applies with regard to the focal treatment of the European law market. There is, of course, a similar market in other regions as well, particularly in and between the United States of America. Although this article makes comparisons with the law market in the United States, the focus here is the European perspective, especially considering that the framework conditions for the law market differ significantly between the United States and Europe.

On its face, the issue of "law as a product" is relatively profane in character. However, this article shows that the subject raises significant philosophical questions, particularly in regard to legal policy conclusions that may be drawn from assessing the emerging market for law. These philosophical issues cannot be exhaustively discussed here. However, an answer will be given to the question of which conceptual course-setting elements are decisive for recommending or not recommending certain framework conditions for the law market.

Part II discusses the emergence of the transnational law market, while part III discusses some of its more important segments. Part IV analyzes characteristics and effects of the law market, while part $\mathrm{V}$ examines the special role of transnational corporations as market actors. Part VI presents a normative assessment of the law market, and part VII develops some policy recommendations with respect to the European governance framework. Concluding remarks follow in part VIII.

\section{EMERGENCE OF A TRANSNATIONAL LAW MARKET}

Market activity only arises if there is supply and demand for a particular product or service. The fact that law has become a product across broad subjects and regions is linked to structural changes on the supply-and-demand side of law as a commodity.

\section{A. Demand Side}

On the demand side, the ability to choose which law shall apply (i.e., conflict of laws options) in global transactions has made the law market

6. See ERIN A. O'HARA \& LARRY E. RIBSTEIN, ThE LAW MARKET 161-81, 183-98 (2009). 
possible. In addition, technological changes have occurred, which make an informed choice significantly easier.

\section{Expanded Opportunities for Choice of Law}

Anyone dissatisfied with the legal rules of a certain jurisdiction can leave the country, at least in cases that do not involve a dictatorial regime, and find comfort in a state that has more preferable laws. In doing so, one escapes the regulatory dictates of the country in which she previously lived. Historically, physical exit was often the only possibility of expressing dissatisfaction. ${ }^{7}$ In some respects, this is still the case today. Anyone seeking to legally escape taxation by a country must, in most cases, actually move his place of residence or his business activities out of that country. The situation is similar in another sphere of life, namely marriage, where temporary departure from one's own jurisdiction is normally necessary in order to make use of more liberal marriage provisions (i.e., "wedding tourism").

Fundamental change has now resulted from the fact that free choice of law is on the advance with regard to numerous issues in the private international law of many countries. ${ }^{8}$ This applies to the same extent both in Europe and the United States, but less so in many Latin American jurisdictions. ${ }^{9}$ Certainly, this development was and is not driven by a desire to make law a product. Choosing freely in private international law is, instead, regarded as an instrument to increase legal certainty with respect to the applicable law and, at the same time, to strengthen private autonomy. ${ }^{10}$ With these expanded opportunities

7. For a fundamental discussion of various control mechanisms in relation to the performance of private and public institutions, see ALBERT O. HIRSCHMAN, EXIT, VOICE, AND LOYALTY: RESPONSES TO DECLINE IN FIRMS, ORGANIZATIONS, AND STATES (1970).

8. For overviews, see O'HARA \& RIBSTEIN, supra note 6, at 37.84 (citing chapters describing choice-of-law principles and the creation of a "law market"); Giesela Rühl, Party Autonomy in the Private International Law of Contracts: Transatlantic Convergence and Economic Efficiency, in CONFLICT OF LAWS IN A GLOBALISED WORLD 153, 155-75 (Eckart Gottschalk et al. eds., 2007). One reason for this development is certainly that physical exit has become easier and cheaper. This enables individuals and companies to exert pressure regarding the recognition of a conflict of laws choice of law. For a comparative analysis of the "federal conflicts law" in the U.S. and Europe, see Jürgen Basedow, Federal Choice of Law in Europe and the United States - A Comparative Account of Interstate Conflicts, 82 TUL. L. REV. 2119-46 (2008).

9. See, e.g., Jürgen Basedow, The Recent Development of the Conflict of Laws: Some Comparative Observations, in JAPANESE AND EUROPEAN PRIVATE INTERNATIONAL LAW IN COMPARATIVE PERSPECTTVE 3, 14 (Jürgen Basedow et al. eds., 2008) (including further references).

10. See Jan Kropholler, InTernationales Privatrecht $\$$ 21(II), 40(III) (6th ed. 2006) (Ger.); Friedrich K. Juenger, Parteiautonomie und objektive Anknüpfung im EG- 
for choice of law, however, come increasing opportunities to choose foreign law without having to physically leave the home country, which means considerably lower costs. In principle, escape from mandatory provisions under national law is also possible. Finally, market actors can combine the regulations of different countries with one another, as seen by our Italian entrepreneur in the initial example. It is possible to choose from the different laws offered in various countries based upon what is most favorable for one's own interests in the relevant sphere of life-thus, laws can be "unbundled."11

Expanded opportunities for choice of law do not only exist at the level of conflict of laws. The potential subject matters of such conflict of laws choices have also increased considerably in the recent past. This applies in particular to Europe, where the European Union has enriched the law products of the individual EU Member States. In European company law, there is, for instance, the European Public Company (Societas Europaea or SE), which may well be joined in the near future by a European Private Company (Societas Privata Europaea or SPE). ${ }^{12}$ Hence, expanded opportunities for choice exist because of changes in private international law and due to altered substantive law products. Taken together, these developments provide for increased opportunities for legal arbitrage and, thus, enable competition for legal rules-law can be selected and deselected by market actors. ${ }^{13}$

These considerations demonstrate also that the market for law products does not and cannot exist without a foundation of legal rules. On the contrary, the law market is instead a function of the applicable law that grants the choice of law opportunities, both in conflict of laws and in substantive law. A change in the conditions of the applicable legal framework automatically facilitates a change in the structure of the law market. I will return to this point later.

\section{Increased Ease in Choice of Law}

In addition to the expanded choice of law opportunities on the demand side, it is most notably the increased ease in choice of law that

Übereinkommen zum Internationalen Vertragsrecht, 46 RABELS ZEITSCHRIFT FÜR AUSLÄNDISCHES UND INTERNATIONALES PRIVATRECHT [RABELSZ] 57, 63-68 (1982) (Ger.).

11. See, e.g., Peter Behrens, Economic Law Between Harmonization and Competition: The Law \& Economics Approach, in ECONOMIC LAW AS AN ECONOMIC Good 45, 54-55 (Karl Meessen et al. eds., 2009).

12. Commission of the European Communities, Proposal for a Council REgUlation ON THE STATUTE FOR A EUROPEAN PRIVATE COMPANY (2008), available at http://ec.europa.eu/internal_market/company/docs/epc/proposal_en.pdf.

13. See Hein Kötz, Deutsches Recht und Common Law im Wettbewerb, ANWALTSBLATT [ANWBL] 1, 7 (2010) (Ger.). 
has contributed to the emergence of the law market and continues to do so. Technical progress, particularly the Internet, has lowered information and transaction costs considerably, thereby creating the possibility of choosing the best law for individual purposes swiftly and efficiently. Information and transaction intermediaries also contribute to the choice of law by providing professional assistance. For example, anyone wishing to form a foreign company or file for bankruptcy abroad can make use of numerous service providers. Thus, informed choice has become much easier and more accessible. Concerning company law, the English limited company is being intensely promoted, particularly in response to German demand, and professional support is being offered for foreigners who wish to form an English limited company. ${ }^{14}$ With respect to insolvency law for individuals, France in particular has become the target for such agents as the "jurisdiction of choice" and is apparently highly attractive to German clientele. ${ }^{15}$

\section{B. Supply Side}

The emergence of a transnational market for legal products is not only based on fundamental changes on the demand side. The existence of any market also presupposes suppliers who compete with each other. In the case of legal products, this means that there must be incentives for the participating jurisdictions to market their wares.

With respect to competition for investments, the incentives are obvious. If firms locate investments in their territory, countries profit in terms of higher taxes, employment, and contribution to their GDP. However, there are similar incentives with respect to the competition for legal rules. In the United States, for example, the existence of a market for company law is all but a recent development. ${ }^{16}$ It is the small East Coast state of Delaware that by far plays the leading role. Approximately sixty percent of the 500 largest U.S. companies are incorporated in Delaware and are therefore subject to its company law. ${ }^{17}$ The state of Delaware has massive incentives to facilitate such

14. See, e.g., GO AHEAD: DIE GRÜNDER, http://www.go-limited.de (last visited Feb. 23, 2011).

15. See VERBRAUCHERINSOLVENZ, http://www.sda-europe.de (last visited Feb. 23, 2011).

16. As to the historical emergence of a market for company law, accounting for the U.S. and the European Union level, see Richard M. Buxbaum, Is There a Place for a European Delaware in the Corporate Conflict of Laws?, 74 RABEL J. COMP. \& INT'L PRIVATE L.1, 9-13 (2010).

17. See Matt Stevens, Internal Affairs Doctrine: California versus Delaware in a Fight for the Right to Regulate Foreign Corporations, 48 B.C. L. Rev. 1047, 1049 (2007); see also About Agency, DEPARTMENT OF STATE: DIVISION OF CorPorations, http://www.corp.delaware.gov/aboutagency.shtml (last visited Feb. 23, 2011). 
incorporations. It obtains more than twenty percent of its entire annual tax revenue from incorporation and franchise fees. ${ }^{18}$ By contrast, EU Member States cannot charge such taxes or fees on the basis of the applicable legal conditions. ${ }^{19}$ Therefore, they lack the direct financial incentives to market their laws the way Delaware does. This likewise applies to the other areas of the law discussed here.

However, indirect financial incentives are presumably far more important than direct financial incentives. If the law of a country is used in various territories worldwide, then it means that the country's specialized service providers (e.g., lawyers, tax advisors, and accountants) also do well. ${ }^{20}$ They, of course, contribute to the country's GDP and also pay taxes. Former English Secretary of State for Justice Jack Straw is very aware of this. In his foreword to the above-cited brochure published by the Law Society he writes, "the success of the legal services sector plays an unquantifiable role in helping London to maintain its position as a major centre for global commerce." 21 In addition, the export of a country's own law also makes it easier for that country's real economy to succeed in foreign markets. If the legal infrastructure in a foreign environment is familiar, establishment in this environment is easier. The difficulty in quantifying this advantage does not change the fact that it exists and presumably carries considerable weight. There is no other way to explain the enormous efforts made by individual countries to export their laws. ${ }^{22}$

\section{The Transnational Law Market as a Recent Phenomenon}

Competition for investments has existed for a long time. Choice of law opportunities, particularly in the private international law regimes of many countries, have as well, albeit to a lesser extent. The

18. OfFICE OF MGMT. \& BUdGeT, Governor's FISCAL YEAR 2010 RECOMMENDED BUDGET 5, available at http://budget.delaware.gov/fy2010/operating/10opfinsumcharts.pdf (last visited Feb. 23, 2010).

19. See Council Directive 69/335, arts. 2(1), 10, 12, 1969 O.J. (L 249) 25 (EC) (concerning indirect taxes on the raising of capital).

20. These advantages are underestimated by EVA-MARIA KIENINGER, WETTBEWERB Der Privatrechtsordnungen IM EURopäIschen BINNENMARKT 190 (2002) (Ger.). Naturally, not only the advisory sector in the home country profits, but also the advisory sector on the home country law in a foreign country. However, the advantages for the first-mentioned group probably predominate (to a large extent).

21. THE LAW SoC'Y OF ENG. \& WALES, supra note 1, at 5.

22. For example, the (German) Gesellschaft für Internationale Zusammenarbeit (GIZ) $\mathrm{GmbH}$, whose sole shareholder is the Federal Republic of Germany, spent over EUR 1 billion on corresponding development projects in 2010. Über die GIZ, GIZ, http://www.giz.de/de/profil.html (last visited Mar. 20, 2010). 
transnational law market developed as a result of the considerable increase of choice of law opportunities on the demand side, and the marketing of substantive law (i.e., the law products) by individual countries on the supply side. It can no longer be disputed that such a law market exists today in numerous regions and in many substantive fields of the law.

As already touched upon, the title of the German Ministry of Justice brochure, "Law made in Germany," alone speaks volumes. In addition, various institutions assess the quality of the law in different jurisdictions today (e.g., in the form of ranking lists, such as the "Global Competitiveness Report" of the World Economic Forum). ${ }^{23}$ The World Bank's "Doing Business Reports" even more clearly demonstrate this phenomenon of global regulatory competition. ${ }^{24}$ In these reports, countries are judged according to how well their law fulfills certain functional requirements. For example, the ranking regarding the ease of formation of a company places Germany at number 102 (United States: 6, United Kingdom: 8, and France: 14). It is apparently very difficult to form a company in Germany. Moreover, the ranking list for the ease of transfer of real estate shows France at number 166 (United States: 12, United Kingdom: 22, and Germany: 52), indicating that it is very difficult (i.e., requiring significant effort with respect to time and costs) to acquire or to mortgage real estate in France. While the underlying methodology of these ranking lists must be criticized, ${ }^{25}$ it does nothing to alter the lists' influence on development policy and important loanmaking decisions. It also does not change the conspicuous fact that they reveal to what extent countries compete with each other for the "best law." Finally, and in the meantime, regulatory competition is further evidenced by the fact that an alignment process related to legal concepts

23. Klaus Schwab \& Michael E. Porter, The Global Competitive Report 20082009, WORLD ECONOMIC FORUM 3-4 (2008), available at http://www.weforum.org/ pdf/GCR08/GCR08.pdf.

24. World Bank, Economy Rankings, DoING BuS., http://www.doingbusiness.org/ rankings (last visited Mar. 2, 2011).

25. See WORLD BANK INDEPENDENT Evaluation Group, DoIng Business: AN INDEPENDENT EVALUATION - TAKING THE MEASURE OF THE WORLD BaNK-IFC DoING BUSINESS INDICATORS (2008) (evaluating the burden of selected business regulations in 178 countries). Cf. Priya Lele \& Mathias M. Siems, Shareholder Protection: A Leximetric Approach, 7 J. CORP. LEGAL STUD. 17-50 (2007), available at http://ssrn.com/abstract= 897479 (criticizing the underlying methodology of the World Bank Business Reports); Mathias M. Siems, Statistische Rechtsvergleichung, 72 RABELS ZEITSCHRIFT FÜR AUSLÄNDISCHES UND INTERNATIONALES PRIVATREChT [RABELSZ] 354, 368-78 (2008); Holger Spamann, On the Insignificance and/or Endogeneity of La Porta et al.'s 'AntiDirector Rights Index' under Consistent Coding (Harvard Law School John M. Olin Center Discussion Paper No. 7 ECGI - Law, Working Paper No. 67, 2006), available at http://ssrn.com/abstract=894301. 
and ideas has started, reflecting the transnational popularity of certain legal products. ${ }^{26}$

The law market as a phenomenon differs from other related phenomena. First, regulatory competition as it relates to legal products is something different from systems competition. ${ }^{27}$ The former concerns the choice of specific legal rules, not the choice of a system in the broader sense, which includes not only legal rules, but also the infrastructure of a particular country, its education system, and its many other functions. Secondly, the law market is a market for the legal rules of a country. Therefore, it does not involve the establishment of a private-in the sense of nonstate-legal order or a private legal framework by a corresponding act of the participating parties. ${ }^{28}$ Finally, the law market is a legal market. This distinguishes it from bribery or corruption, where legal regulations may be enacted or prepared as consideration for illegal payments. A further differentiation can also be seen with respect to the fact that the law market is a market for generally applicable legal provisions, that is to say rules which do not only apply in special, individual cases. In this respect, the law market differs from, for example, a settlement in civil proceedings or a so-called "plea deal" in criminal proceedings, which merely concern the application of an existing legal provision to specific conduct in an individual case.

\section{SEGMENTS OF THE LAW MARKET}

The phenomenon of the law market is illustrated below by some of its segments, namely company law, contract law, the law of dispute resolution, and insolvency law. In at least some cases, there are respective empirical studies regarding these segments that go beyond merely showing which jurisdictions are the market leaders. These studies also indicate why certain rules or regulations have been successful in the transnational competition and others not. These

26. See infra Part III (discussing empirical studies that show which jurisdictions are legal market leaders and why certain regulations have been successful in transnational competition).

27. On systems competition see Karl M. Meessen, Prinzip Wettbewerb, JuRISTENZEITUNG [JZ] 697, 703-06 (2009) (Ger.); Hans-Werner Sinn, The New Systems Competition (Ctr. for Econ. Studies \& Ifo Inst. for Econ. Research, Working Paper No. 623, 2001), available at http://ssrn.com/abstract=296233. See also Charles M. Tiebout, A Pure Theory of Local Expenditures, 64 J. PoL. ECON. 416 (1956) (discussing an economic model for the efficient allocation of public resources that relies on regulatory competition and the mobility of consumer-voters).

28. See Peter Rawert \& Markus Baumanns, Auf nach Transsystemien, FrankFURTER ALlgemeine ZeITUNG [FAZ] (Frankfurt), Mar. 4, 2009, at N5. 
findings are important for the economic assessment of the law market in part VI.

\section{A. Company Law}

As already mentioned, U.S. company law is dominated by Delaware. The decisive reasons for this have yet to be completely explained. ${ }^{29}$ In particular, it remains unanswered whether Delaware's law is attractive because it is more efficient than that of other states, or whether other factors like preferential treatment for the management, network effects, and path dependence play a more important role. Delaware's dominant position relates not only to large corporations, but also to limited liability companies. Limited liability companies are partnerships, which are treated as such for tax purposes, but offer their partners limited liability. A recent survey has shown Delaware as the leader in this respect as well. ${ }^{30}$

In Europe, regulatory competition in company law did not play a significant role for a long time due to the real seat principle in the conflict of laws of many different Member States. The real seat principle states that the law applicable to a company is the law of the state in which the company has its real seat (i.e., where its central place of administration is located). This changed fundamentally with three major decisions from the European Court of Justice: Centros, Überseering, and Inspire Art, ${ }^{31}$ which all concerned the freedom of establishment. ${ }^{32}$ These decisions resulted in Member States having to recognize a company formed in another Member State according to its law of formation, even if the company has never operated in the country of formation. This effectively established the possibility of choice for founders of the applicable company law. Given that the differences between the company law systems of European Member States are significantly greater than those in the United States, frequent use of this choice of law could be expected.

29. See infra Part VI.B.1.b.

30. See Jens Dammann \& Matthias Schündeln, Where Are Limited Liability Companies Formed? An Empirical Analysis 5 (Univ. of Tex. Sch. of Law, Law \& Econ. Research Paper No. 126, 2008), available at http://ssrn.com/abstract=1126257 (noting that around $50 \%$ of the LLCs with more than 1,000 employees are formed outside their home state and of these, in turn, more than $80 \%$ in Delaware).

31. Case C-167/01, Kamer van Koophandel en Fabrieken voor Amsterdam v. Inspire Art Ltd., 2003 E.C.R. I-10155; Case C-208/00, Überseering BV v. Nordic Constr. Co. Baumanagement GmbH, 2002 E.C.R. I-9919; Case C-212/97, Centros Ltd. v. Erhvervs-og Selskabsstyrelsen, 1999 E.C.R. I-1459.

32. Consolidated Version of the Treaty on the Functioning of the European Union arts. 49, 54, Sept. 5, 2008, 2008 O.J. (C 115) 67, 69. 


\section{Closed Corporations}

This is precisely what happened, primarily and initially for closed corporations (i.e., on the market for start-up entrepreneurs). The English private company limited by shares (Ltd.), in particular, proved to be very popular in the German market for the formation of companies. It is difficult to ascertain the precise number of "German" Ltds., as the obligatory requirement to register a branch or trade in the country of operation is not fulfilled by all entrepreneurs. More accurate results in this context could be obtained by looking at the places of residence of the business managers. A residence exclusively in Germany is a strong indication of a "German" Ltd. On this basis, almost every fifth newly formed, closed corporation in Germany in 2005 was an English Ltd., instead of a German limited liability company (GmbH). In 2006, at the height of the Ltd. boom, almost every fourth newly formed closed corporation in Germany was an Ltd. ${ }^{33}$ At the end of 2006, approximately 40,000 "German" Ltds. existed in Germany. Simple econometric analyses revealed what made the Ltd. so popular: the lack of a minimum capital requirement and the speed of incorporation. ${ }^{34}$ Some, therefore, consider that this development has been less a competition for the best law, but rather a market for cheap company formation. ${ }^{35}$ The Ltd. has been a popular legal form predominantly in Member States where the costs of establishing a branch are comparatively low (incorporation agents play an important part here as well). ${ }^{36}$ Interestingly, the competition can only be partially interpreted as crowding out competition. The total number of closed corporations formed by Germans increased respectively in 2003, 2004, 2005, and 2006. Obviously, the Ltd. appealed to a clientele of founders who would not have formed a closed corporation without the possibility of using this legal form.

33. Horst Eidenmüller, Die GmbH im Wettbewerb der Rechtsformen, 36 ZEITSCHRIFT FÜR UNTERNEHMENS- UND GESELLSCHAFTSRECHT [ZGR] 168, 172-74 (2007) (Ger.). For more details and statistics on the popularity of the English Ltd. among German entrepreneurs, see Marco Becht et al., Where Do Firms Incorporate? Deregulation and the Cost of Entry, 14 J. CoRP. Fin. 241, 241 (2008).

34. See Becht et al., supra note 33, at 250-52.

35. See William W. Bratton et. al., How Does Corporate Mobility Affect Lawmaking? A Comparative Analysis, 57 AM. J. CoMP. L. 347, 374-80 (2009). By contrast, as here (regulatory competition), Daniel Zimmer, Zwischen Theorie und Empirie: Zur Konkurrenz der Gesetzgeber im Gesellschaftsrecht, in FESTSCHRIFT FÜR KARSTEN SCHMIDT ZUM, 70 GEBURTSTAG 1789, 1796-1800 (Georg Bitter et al. eds., 2009) (Ger.).

36. See Marco Becht et al., Centros and the Cost of Branching, 9 J. CoRP. L. STUD.171, 181-83 (2009), available at http://ssm.com/abstract=1433311. 
The popularity of the Ltd. had a historic precursor. More than one hundred years ago, its popularity served as a reason for the creation of the $\mathrm{GmbH}$ Act and the first-time establishment of a closed corporation entity in Germany. ${ }^{37}$ One hundred years later, the phenomenon appeared again, this time for other reasons and with greater force, and it did not take long for the EU Member States to react. The Sociedad Limitada Nueva Empresa was launched in Spain in 2003, which allowed a company to be formed with a minimum capital of $€ 3,012$ and within only twenty-four hours. ${ }^{38}$ In 2003 and 2004, France fundamentally reformed the law of the Societé à responsabilité limitée and abolished the minimum capital requirement. ${ }^{39}$ Finally, Germany followed with the $\mathrm{GmbH}$ reform in 2008, which led to the establishment of a new type of company, the Unternehmergesellschaft (haftungsbeschränkt), a limited liability company entity for entrepreneurs. In essence, this corporate form is a $\mathrm{GmbH}$ without a minimum capital requirement. At first glance, one might assume that the somewhat clumsy title given this type of entity would put people or would-be businesses off. However, the number of formations indicates that the Unternehmergesellschaft is a huge success. ${ }^{40}$ As a result, the Ltd. has already lost part of its market share in the German start-up market.

\section{Public Corporations}

A European law market for corporations also exists for public corporations. As with closed corporations, English law is obviously extremely attractive for large public corporations. For example, the German airline Air Berlin operates in the legal form of a public limited company by shares. However, the European Societas Europaea (SE) also enjoys a certain popularity, precisely and particularly in Germany. Large German corporations such as Allianz, Porsche, BASF, Fresenius,

37. See Holger Fleischer, Introduction to 1 MÜNCHENER KOMMENTAR ZUM GESETZ BETREFFEND DIE GESELLSCHAFTEN MIT BESCHRÄNKTER HAFTUNG - GMBHG, I 56 (Holger Fleischer \& Wulf Goette eds., 2010) (Ger.) (author's translation).

38. Ley 7/2003 arts. 134(6)-(10), 135(1) (B.O.E. 2003, 79) (Spain). See José Miguel Embid Irujo, Eine spanische "Erfindung" im Gesellschaftsrecht: Die "Sociedad limitada nueva empresa" - die neue unternehmerische GmbH, 50 RECHT DER INTERNATIONALEN WIRTSCHAFT [RIW] 760, 760-67 (2004) (Ger.).

39. Loi 2003-721 pour l'initiative économique of August 4, 2003 (Fr.). See Horst Eidenmüller et al., Minimum Capital within the System of Legal Capital, in 1 EUR. Co. \& FiN. L. REV. [E.C.F.R.] 17, 37 \& n.72 (Marcus Lutter ed., 2006).

40. See, e.g., Wilhelm Niemeier, Erste Startkapitalisierungsdaten der "UG": Mit Schwung in die kapitallose Unternehmensgründung?, DER BETRIEB STATUS RECHT [DB] 74, 74 (2009) (Ger.) (reporting 4,820 UG-registrations in the first four months of the existence of the new legal form). 
and MAN have decided in favor of this legal form. In fact, 70 of the total 213 SEs in existence in June 2008 (i.e., approximately one-third) were located in Germany. ${ }^{41}$

Regression analyses show the factors that are responsible for the popularity of the SE in Germany. ${ }^{42}$ Primarily, founders are concerned with avoiding codetermination on the (supervisory) board level if possible, or at least mitigating its effects. For example, if thresholds for employee figures of 500 or 2000 are likely to be exceeded, an SE may be formed to "freeze" the existing level of codetermination. ${ }^{43}$ However, even in cases where a company already has more than 2000 employees, an $\mathrm{SE}$ can be used as a vehicle to mitigate the effects of codetermination by equal representation on the supervisory board. Although the relevant European and Member States' rules provide that the most rigid codetermination provisions prevail if the relevant parties fail to reach a mutual agreement on workers' representation in an SE, ${ }^{44}$ the capital side can unilaterally reduce the size of the supervisory board in an SE. 45 Moreover, in an SE, such a board-in contrast to, for example, a German national stock corporation-has a mandatory international composition. From the point of view of the investors, this is obviously an advantage: divide et impera.

\section{B. Contract Law}

In the United States, the contract law market is dominated not by the law of Delaware, but by the law of New York. According to a recent study of important business law contracts, New York law is chosen for

\footnotetext{
41. See Horst Eidenmüller et al., Die Societas Europaea: Empirische Bestandsaufnahme und Entwicklungslinien einer neuen Rechtsform, DIE AKTIENGESELLSCHAFT [AG] 721, 725 (2008) (Ger.).

42. See Horst Eidenmüller et al., Incorporating Under European Law: The Societas Europaea as a Vehicle for Legal Arbitrage, 10 EUR. BUS. ORG. L. REV. [E.B.O.R.] 1, 31-33 (2009).

43. Under German law, in a public corporation with more than 500 employees, onethird of all members of the supervisory board must be worker representatives. In a public corporation with more than 2,000 employees, the quota is one-half.

44. See Art. 7 in conjunction with the standard rules in Part 3 of the Annex of Council Directive 2001/86/EC of October 8, 2001, supplementing the Statute for a European Company with regard to the involvement of employees Council Directive 2001/86, art. 7, Annex Part 3, O.J. (L 294) 3 at 22 (EC); SE-Beteiligungsgesetz [SEBG][Act on the Employee Involvement in an SE], Dec. 22, 2004, BGBL. I at 3675, $3686 \S \S 34-38$ (Ger.). To date and to my knowledge, there are no cases in which negotiations have failed.

45. Pursuant to Section SE-Beteiligungsgesetz [SEBG] $\S 17(1)$, the minimum number of members of a supervisory board is three; $\S 35(2)$ ensures that the employees are represented, but does not give rise to a claim to retain the original number of employees' representatives.
} 
commercial contracts in $46 \%$ of all cases in which a choice of law provision is included in the agreement. ${ }^{46}$ By contrast, the law of Delaware is chosen in only fifteen percent of all such cases. Where a choice of law provision in a contract provides that New York law shall apply to any disputes arising under the agreement, it is also common to find a clause naming New York as the jurisdiction in which disputes should be settled. Regression analyses show that the popularity of New York law cannot be explained merely by the place of business of the parties, their place of incorporation, or the location of the advising lawyers. ${ }^{47}$ Apparently, the efficiency of court proceedings in New York plays a role, along with the subjectively perceived sensitivity of New York law to the interests of financial institutions. This is a remarkable finding to which I will return later. Above all, the lawyers who are located and provide advice in New York benefit from the popularity of New York law. For them, the choice of law brings additional business.

In Europe too, jurisdictions that have the reputation of being sensitive to the needs of commerce and businesses are often the jurisdictions selected as governing law in business agreements. For example, a representative survey by the University of Oxford of 100 European companies with cross-border activity (a majority (19\%) of the companies involved in the study were German) showed that English law was the most popular and was selected by $23 \%$ of the firms. Swiss law was the second most popular choice and was selected by $19 \%$ of the firms. ${ }^{48}$ If the choice is made excluding the home jurisdiction of one of the contractual partners, Swiss law prevails in $29 \%$ of the cases. Eurobonds of internationally operating European companies are usually subjected to English law. 49

In the Oxford study cited above, the participating companies vaguely indicated that a primary reason for the popularity of English or Swiss law is the quality of their contract law. From a German point of view, this can be stated more specifically: parties to a contract wish to avoid the perceived inappropriateness of judicial review of preformulated, standard contract terms with respect to principles of

46. Theodore Eisenberg \& Geoffrey P. Miller, The Flight to New York: An Empirical Study of Choice of Law and Choice of Forum Clauses in Publicly-Held Companies' Contracts, 30 CARDozo L. REv. 1475, 1478 (2009).

47. See id.

48. Civil Justice Systems in Europe: Implications for Choice of Forum and Choice of Contract Law; A Business Survey-Final Results, INST. EUR. \& CoMP. L.: U. OxFORD FAC. L., 14 (Oct. 1, 2008) http://denning.law.ox.ac.uk/iecl/ocjsurvey.shtml (click the "Summary of survey results" hyperlink) [hereinafter Oxford Study].

49. See The World Bank, Global Development Finance: The Globalization of CoRPorate FinanCE IN DEVEloping COUNTRIES 94 (2007). 
fairness. ${ }^{50}$ The German Federal Supreme Court (Bundesgerichtshof or $\mathrm{BGH}$ ) is, inter alia, criticized for setting too high a standard for the individual negotiation of contractual conditions, ${ }^{51}$ for transferring certain clause prohibitions of the German Civil Code to business-tobusiness commerce without proper reflection, and for failing to give sufficient consideration to its usual customs. ${ }^{52}$ In addition, the BGH classifies bond conditions as standard contract terms, which are, at least in principle, subject to judicial review pursuant to the provisions on unfair contract terms of the German Civil Code, if the bond is subject to German law. ${ }^{53}$ In both cases, foreign law obviously offers stronger protection for formal private autonomy. Swiss law does not provide for a general judicial review of standard terms in legal transactions between companies, nor where consumers are involved. ${ }^{54}$ According to English law, bond conditions are not subject to judicial scrutiny of standard terms either. Instead, they are considered part of the product of the securities sold and, therefore, are not subject to review. ${ }^{55}$

50. See Sebastian Brachert \& Andreas Dietzel, Deutsche AGB - Rechtsprechung und Flucht ins Schweizer Recht, ZEITSCHRIFT FÜR DAS GESAMTE SCHULDRECHT [ZGS] 441, 441 (2005) (Ger.); Paul Hobeck, Flucht aus der deutschen Gerichtsbarkeit bei wirtschaftsrechtlichen Streitigkeiten - warum?, DEUTSCHE RICHTERZEITUNG [DriZ] 177, 178 (2005) (Ger.); Kötz, supra note 13, at 3-4; Michael Abels, Gerichte zerstören Vertrauen, FranKFuRTER ALIGEMEINE ZEITUNG [FAZ] (Frankfurt), 19 (2007) (Ger.).

51. According to Bürgerliches GesETZBUCH [BGB] [CIVIL CODE] Jan. 2, 2002, BUNDESGESETZBLATT I [BGBL. I], § 305(1) (Ger.), freely negotiated contractual clauses are not subject to judicial review with regard to the German provision on unfair contract terms.

52. For more detail see Klaus Peter Berger, Abschied von der Privatautonomie im unternehmerischen Geschäftsverkehr?, ZEITSCHRIFT FÜR WIRTSCHAFTSRECHT [ZIP] 2149 56 (2006) (Ger.); Karlheinz Lenkaitis \& Stephan Löwisch, Zur Inhaltskontrolle von AGB im unternehmerischen Geschäftsverkehr: Ein Plädoyer für eine dogmatische Korrektur, ZEITSCHRIFT FÜR WIRTSCHAFTSRECHT [ZIP] 441-49 (2009) (Ger.) (providing extensive evidence from the case-law of the German Federal Supreme Court).

53. See Bundesgerichtshof [BGH] [German Federal Court of Justice] June 28, 2005, 163 BGHZ [Entscheidungen des Bundesgerichtshofs in Zivilsachen] 311, 313-19 (Ger.) (qualifying bond conditions as standard terms). For a detailed discussion of the problem, see HORST EIDENMÜLLER, UNTERNEHMENSSANIERUNG ZWISCHEN MARKT UND GESETZ: MECHANISMEN DER UNTERNEHMENSREORGANISATION UND KOOPERATIONSPFLICHTEN IM REORGANISATIONSRECHT 214-23 (1999) (Ger.) (citing further references).

54. See Nathalie Voser \& Christopher Boog, Die Wahl des Schweizer Rechts - was man wissen sollte, 55 RECHT DER INTERNATIONALEN WIRTSCHAFT [RIW] 126, 133 (2009) (Ger.) (containing further references).

55. See Lachlan Burn, Bond Issues Under U.K. Law: How the Proposed German Legislation Compares, in DIE REFORM DES SCHULDVERSCHREIBUNGSRECHTS 219, 223-28 (Theodor Baums \& Andreas Cahn eds., 2004) (Ger.). Certain mandatory provisions may result from trust law and securities law. However, English law on consumer protection concentrates less on mandatory substantive law and more on the regulation of the sellers of bonds, see id. at 226-28. 
The Federal Government of Germany is thoroughly aware of the declining importance of German law for bond issues of companies that operate internationally. In an interview with then-Minister of Justice Brigitte Zypries, published in May 2008, she said, "It is not that German issuers no longer choose German law at all. But we have found that many of them prefer foreign law." 56 In the meantime, the German Bond Act has been reformed with an effective date of August 5, 2009.57 The reform brought about substantial improvements, particularly for the restructuring of bonds of distressed debtors. However, the judicial review of bond conditions remained, at least in principle, unchanged.

\section{Law of Dispute Resolution}

The dominance of English and Swiss law continues in the field of dispute resolution. For most of the companies questioned in the Oxford study (17\%), English courts are the preferred dispute resolution forum. ${ }^{58}$ If the respective home jurisdiction is not chosen, Swiss courts dominate (21\%). ${ }^{59}$ The primary reasons given for preferring English and Swiss forums for dispute resolution are the quality of the judges and courts, as well as the United Kingdom having the "most favorable" civil justice system in Europe (a response given by $26 \%$ of the companies studied). ${ }^{60}$

Today, however, large commercial disputes are predominantly resolved within arbitration proceedings (63\% of the companies studied prefer arbitration to court proceedings when conducting cross-border transactions). ${ }^{61}$ There are many reasons for this. ${ }^{62}$ Arbitration proceedings lead to a final decision in a relatively short time. The parties can choose expert arbitrators. Most of all, the proceedings are confidential and, therefore, less of a burden on the existing business relationship.

56. Interview mit Brigitte Zypries: Schuldverschreibungsrecht "wird moderner", BÖRSEN-ZEITUNG (Frankfurt), May 13, 2008, at 7.

57. SCHULDVERSCHREIBUNGSGESETZ [SCHVG] [ACT ON THE NEW REGULATION OF THE LEGAL RELATIONS FOR DEBENTURES AND IMPROVED ENFORCEMENT OF INVESTORS' CLAIMS RESUlTING FROM WRONG ADVICE], July 31, 2009, BUNDESGESETZBLATT I [BGBL. I] 2512 (Ger.).

58. Oxford Study, supra note 48 , at 26.

59. Id. at 27.

60. Id. at 35-36.

61. See id. at 45 .

62. See Christian Bühring-Uhle et al., ARBITRATION AND MEDIATION IN INTERNATIONAL BUSINESS 63-67 (2d ed. 2006); KARL HEINZ SchWAB \& GERHARD WALTER, SCHIEDSGERICHTSBARKEIT ch. 1 \% 8 ( 7 th ed. 2005) (Ger.). 
Arbitration proceedings are usually subject to the procedural regulations at the place of arbitration, ${ }^{63}$ which can be chosen at will. ${ }^{64}$ In principle, according to the New York Convention, ${ }^{65}$ arbitral awards must be recognized by all signatory countries. Just as the parties are free to choose the place of arbitration and, therefore, the secondarily applicable state procedural law, they can also regulate the proceedings themselves, subject to certain mandatory principles, or refer to the procedure rules of an arbitration institution. ${ }^{6} 6$

Systematic empirical investigations related to the popularity of individual places of arbitration and procedural law and rules do not exist to date. However, the published material on the number and volume (i.e., amounts in dispute) of administrated arbitration proceedings indicates that the most favored venues for arbitration in Europe are Switzerland (e.g., Chambers of Commerce of Basle, Bern, Geneva, Lausanne, Lugano, and Zurich), Paris (e.g., International Chamber of Commerce), and London (e.g., London ICC International Court of Arbitration). ${ }^{67}$ There appear to be a series of decisive reasons for these preferences. The first reason is the subjectively perceived neutrality of individual places of arbitration, which applies to Switzerland in particular. The second reason is the historically established professionalism associated with arbitration institutions involved in these jurisdictions, along with their well-known and efficient methods for administration of cases. Finally, ease in dealing with the applicable substantive law is certainly also important. If, as happens frequently, the parties declare Swiss or English law applicable as the governing law of contract regarding dispute resolution, it is only natural to call on an arbitration tribunal of experts in Switzerland or England.

63. See, e.g., ZivilProzessordnung [ZPO] [COde of Civil Procedure], Dec. 5, 2005, BUNDESGESETZBLATT I [BGBL. I] 3202, as amended, § 1025(1) (Ger.).

64. Id. $\S 1043(1)$.

65. U.N. Conference on International Commercial Arbitration, Convention on the Recognition and Enforcement of Foreign Arbitral Awards, adopted June 10, 1958), 330 U.N.T.S. 38, available at http://www.uncitral.org/uncitral/en/uncitral_texts/arbitration/ NYConvention.html.

66. ZPO § 1042(3)

67. As to the Chambers of Commerce of Basle, Bern, Geneva, Lausanne, Lugano, and Zurich, see Arbitration Statistics 2008, Swiss Chambers' CT. ARB. \& MEDIATION, https://www.sccam.org/sa/download/statistics_2008.pdf (last visited Mar. 6, 2011). Statistics for the International Chamber of Commerce in Paris can be found at Facts and Figures on ICC Arbitration: Statistical Reports, INT'L CHAMBER COM., http://www.iccwbo.org/court/arbitration/id5531/index.html (last visited Mar. 6, 2011). The London Court of International Arbitration's website is available at http://www.lcia.org/ (last visited Mar. 6, 2011). 


\section{Insolvency Law}

Insolvency law is a fourth field providing useful insights into the development of the law market in Europe. The European Insolvency Regulation (EIR) ties international jurisdiction regarding principal insolvency proceedings to the "centre of main interests" (COMI) of an individual or a company. ${ }^{68}$ If insolvency proceedings are commenced in one jurisdiction, they are in principle subject to its procedural rules (i.e., to the lex fori). ${ }^{69}$

One of the main aims of the EIR is to prevent forum shopping. ${ }^{70} \mathrm{In}$ practice, however, this aim has not been fulfilled. On the contrary, the COMI criterion is fact sensitive and susceptible to manipulation. This applies in particular, but not exclusively, in situations concerning the insolvency of a corporate group. ${ }^{71}$ In practice, forum shopping has become an everyday legal reality when it comes to insolvency proceedings. This is so in spite of a decision by the European Court of Justice that sought to limit such strategic tactics. ${ }^{72}$

For companies, England once again proves to be the preferred safe haven. For example, prominent German enterprises such as Schefenacker and Deutsche Nickel were transformed into English companies and subsequently restructured in London. ${ }^{73}$ There are a couple of reasons for businesses seeking a restructuring in England. ${ }^{74}$ In English insolvency proceedings, creditors have greater control over the course of the proceedings. In particular, they can appoint an insolvency administrator, which is not possible under German law. English insolvency proceedings are also considered swift, and they permit the implementation of efficient restructuring techniques, such as debtequity swaps. This is not as easily done in Germany. ${ }^{75}$ Again, the

68. Council Regulation 1346/2000, EC Regulation on Insolvency Proceedings, art. 3(1), 1990 0.J. (L 160) 1, 5 (EC).

69. Id. art. $4(1)$.

70. Id. recital (4).

71. See Horst Eidenmüller, Wettbewerb der Insolvenzrechte?, 35 ZEITSCHRIFT FÜR UNTERNEHMENS- UND GESELLSCHAFTSRECHT [ZGR] 467, 474-79 (2006) (Ger.) (citing further references).

72. See Case C-341/04, Eurofood IFSC Ltd, 2006 E.C.R. I-3813, ๆ 69(1)-(4).

73. See John Willcock, German Restructurings Head to London, INSOL WORLD, 4th Q. 2006, at 14, 14-15, available at http://www.insol.org/newinsolworld/2006/ 4thQuarter2006.pdf.

74. See Horst Eidenmüller, Leveraged Buyouts und die Effizienz des deutschen Restrukturierungsrechts, 2007 ZEITSCHRIFT FÜR WIRTSCHAFTSRECHT [ZIP] 1729, 1733-37 (Ger).

75. See Horst Eidenmüller \& Andreas Engert, Reformperspektiven einer Umwandlung von Fremd- in Eigenkapital (Debt-Equity Swap) im Insolvenzplanverfahren, 2009 ZEITSCHRIFT FÜR WIRTSCHAFTSRECHT [ZIP] 541, 542-43 (Ger.). 
German legislature is well aware of the weaknesses of current German company insolvency law. Thus, the Ministry of Justice has established two expert commissions whose task is to prepare recommendations for improving the status quo. ${ }^{76}$ Recently, plans for reforming the German Insolvency Code (Insolvenzordnung) were released. ${ }^{77}$

While historically English law and England's place as a forum have been of great importance to corporate restructurings, Germans have recently begun to navigate their private insolvency matters to France. ${ }^{78}$ This has less to do with the perception of a generally better quality of life in France, but rather with the different system of residual debt discharge permitted in France. Discharge can be obtained under German insolvency law as well, but only six years after the commencement of insolvency proceedings.79 By contrast, in certain départements, French insolvency law offers discharge immediately after insolvency proceedings. ${ }^{80}$ This, of course, provides a strong incentive to establish jurisdiction for insolvency proceedings in France.

\section{CHARACTERISTICS AND EFFECTS OF THE LAW MARKET}

Looking back at the description of individual segments of the European law market, one notes certain characteristics and effects of this market, which are important for its further analysis and resulting policy recommendations. The development outlined above has consequences for some of the central categories of the polity, such as state, territory, and law.

76. The first of the two commissions deals with reform issues of company insolvency law in general. The second commission deals with these insolvency issues in group scenarios.

77. The text of these plans can be found in Diskussionsentwurf des BMJ für ein Gesetz zur weiteren Erleichterung der Sanierung von Unternehmen [Discussion Document of the Federal Ministry of Justice on an Act for the Further Facilitation of the Reorganization of Distressed Corporations], 2010 ZEITSCHRIFT FÜR WIRTSCHAFTSRECHT [ZIP] 1 (Supp. I), which available at http://www.jura.uni-duesseldorf.de/dozenten/noack/Texte/InsOReform\%20DiskE.pdf (Ger.).

78. See Bärbel Nückles, Nach Frankreich des Konkurses wegen, FRANKFURTER ALlGemeine ZeItUNG [FAZ] (Frankfurt), Jan. 29, 2008, at 11; Reinhold Rühl, SchuldenTourismus mit Hindernissen, SüDDEUTSCHE ZEITUNG [SZ] (Munich), Jan. 13, 2008, http://www.sueddeutsche.de/finanzen/925/429678/text/. The U.K. also has been quite popular for German "insolvency refugees," see Uwe Pel, Für Insolvenzflüchtlinge in England brechen härtere Zeiten an, INDAT-REP., no 1., 2010, at 30, 30-31 (Ger.).

79. Insolvenzordnung [InsO] (Insolvency Code), Oct. 5, 1994, BUNDESGESETZBLATT I [BGBL. I] 2866, as amended, $\$ 287$ (2) (Ger.).s

80. See Horst Eidenmüller, Abuse of Law in the Context of European Insolvency Law, 6 EUR. Co. \& FIN. L. REV. 1, 19 (2009), available at http://ssrn.com/abstract=1353932. 
First, the equation between territorial sovereignty of a state and applicable law is increasingly failing to add up. Laws of different jurisdictions "apply" in a particular country, depending on the issues and the groups of persons affected. At the same time, the power of a country to pass binding legislation for activities within its territory is waning, at least when choice opportunities are granted on a supranational level. This disintegration of law and territory calls traditional categorizations in comparative law more and more into question.

Second, there is demand on the law market for law products that satisfy the interests of those who are effectively in the position to influence the choice of law. For instance, in company law, this applies to shareholders and company managers, but not to employees and creditors. In insolvency law, it relates to company managers, shareholders, and large creditors, but not to small creditors. Finally, it applies to the issuers of bonds, but not to their purchasers.

Third, the process of making law appears to be changing. Law is no longer the result of political discourse, but instead the product of supply and demand on international markets. Legal rules no longer appear to be created in a debate about the "right" provisions. Instead, they are apparently "made" by interest-related market forces.

Fourth, the example of arbitration shows that while the law market involves competition between state rules, private rule-makers also compete with one another to the extent that contracting parties can choose their provisions. In arbitration, this is the case because the procedural systems of private arbitration institutions can attain central importance for the respective arbitration proceedings on the basis of corresponding clauses in states' arbitration laws allowing such choice.

Finally, in the choice of legal rules, the popularity of AngloAmerican legal concepts can be clearly recognized. In many areas, these concepts are characterized by their concentration on ex post liability, contrary to the European tradition that instead often focuses on ex ante control. This applies, for example, in the case of company law, in which the European system of a fixed legal capital has come under considerable competitive pressure. It also applies in contract law with regard to the involvement of notaries, who are used as a precautionary measure in the administration of justice prescribed in many legal systems across continental Europe. Finally, the same is also true in the field of dispute resolution. Whereas mediation is an unregulated 
profession in England, license restrictions and other hurdles are currently the subject of intense debate in Germany. ${ }^{81}$

\section{Transnational Corporations as Market ACtors}

What is the role of transnational corporations (TNCs) in the transnational law market? An internationally acknowledged definition of the term "transnational corporation" does not exist. ${ }^{82}$ Trying to fit all traits of those corporations into one model definition would most likely end up in arbitrary phrasing. Instead, the common characteristics of TNCs should be assessed, and the term should be considered as a more generic term that spotlights the most common peculiarities of those businesses. For example, TNCs usually engage in cross-border transactions and maintain subsidiaries, branches, assets, and other significant resources in more than one jurisdiction. ${ }^{83}$ Their economic relevance as market actors can be enormous, particularly for small and mid-size countries. ${ }^{84}$ TNCs can be assumed to be fully rational market actors, and they are repeat players.

With respect to the transnational law market, the specific costbenefit position of TNCs translates into superior choice incentives. As a consequence of their presence in many countries, investment and asset shifting are eased. Further, scale economies can be achieved by applying one model set of terms and conditions, as far as the applicable state law permits, to all contracts in a certain field of business activity worldwide. Finally, engaging in bankruptcy forum shopping is relatively cheaper for TNCs as compared to small or medium-size enterprises.

The superior choice incentives of TNCs create an enlarged set of legal options. TNCs have a strong incentive to engage in "private ordering" (i.e., to use contract rules as a flexible and efficient

81. For this discussion, see Horst Eidenmüller \& Matthias Prause, Die europäische Mediationsrichtlinie: Perspektiven für eine gesetzliche Regelung der Mediation in Deutschland, 2008 NEUE JURISTISCHE WOCHENSCHRIFT [NJW] 2737, 2742-43 (Ger.). See also, Gesetz zur Förderung der Mediation und anderer Verfahren der außergerichtlichen Konfliktbeilegung, BUNDESMINISTERIUM DER JUSTIZ [FEDERAL MINISTRY OF JUSTICE] (Aug. 4, 2010), available at http://www.werner-baurecht.de/media/pdf/Foren/Baukonflikt management/RefE_Mediationsgesetz_20100803.pdf, for a draft statute on mediation.

82. See Katarina Weilert, Transnationale Unternehmen im rechtsfreien Raum? Geltung und Reichweite völkerrechtlicher Standards, 69 Heidelberg J. Int'l L. 883, 886 (2009) (Ger.).

83. See Peter T. Muchlinski, Multinational EnTERPRises and the LAW 5-8 (2d ed. 2007).

84. The revenues of large TNCs can easily exceed the gross domestic product (GDP) of even certain mid-size national economies. For examples, see Weilert, supra note 68 , at 883-84 \& n.1. 
mechanism in designing tailor-made governance regimes for their dealings with business partners, such as suppliers or distributors). As case studies show, powerful corporations often subject such partners to codes of conduct (e.g., as to product quality and labor conditions) and certain other for the corporations favorable contract provisions as a precondition for doing business. ${ }^{85}$ In the absence of transnational regulation in many fields, TNCs fill in the gaps by means of contract. The contracting standardization brought about in international tradeas described by the phrases lex mercatoria and new law merchant, respectively - can partly be ascribed to the standard-setting power of large TNCs. ${ }^{86}$ It appears that "private constitutions" spread and replace statutory law, undermining its regulatory function and the values it embodies. ${ }^{87}$ But this view would be too narrow. It neglects to consider the fact that private ordering is always conditioned by enabling and limiting legal rules and is thus embedded in a specific legal framework (e.g., freedom of contract, enforcement of contracts, recognition of arbitration, and others).

Finally, the excellent choice set of TNCs translates into superior bargaining power. In this regard, the function of nonagreement alternatives is of crucial importance. As is well known, bargaining power is mainly derived from good nonagreement alternatives. ${ }^{88}$ As a consequence of their superior choice set and, hence, nonagreement

85. See Larry Catá Backer, Economic Globalization and the Rise of Efficient Systems of Global Private Law Making: Wal-Mart as Global Legislator, 39 CONN. L. REV. 1739 passim (2007) [hereinafter Backer, Global Private Law Making] (regarding Wal-Mart's forays into private law making, including two case studies in Germany and Jordan); Larry Catá Backer, Multinational Corporations as Objects and Sources of Transnational Regulation, 14 ILSA J. Int'] \& Comp. L. 499, 508-23 (2008) [hereinafter Backer, Multinational Corporations] (using Gap Inc. as a case study); A. Emmerich-Fritsche, Transnationales Recht 3 (unpublished manuscript), available at http://www.oer-alt.wiso.unierlangen.de/Transnationales_Recht.pdf (last visited Mar. 6, 2010) (Ger.). With respect to "private ordering" in general, see Steven L. Schwarcz, Private Ordering, 97 Nw. U. L. REv. 319, 319-20, 324-29 (2002).

86. See Emmerich-Fritsche, supra note 85, at 1-7.

87. For broader accounts on this, see Backer, Global Private Law Making, supra note 85, at 1748-49; Backer, Multinational Corporations, supra note 71, at 517-23; Gralf-Peter Calliess \& Hermann B. Hoffmann, Judicial Services for Global Commerce - Made in Germany?, 10 GERMAN L.J. 115, 118-19 (2009); Günther Teubner, The Corporate Codes of Multinationals: Company Constitutions Beyond Corporate Governance and CoDetermination, in CONFLICT OF LAWS AND LAWS OF CONFLICT IN EUROPE AND BEYOND: PatTerns of Supranational and TRANSNATIONAL JURIDIFICATION 203, 208-10 Rainer Nickel ed., 2010); Günther Teubner, Self-Constitutionalizing TNCs? On the Linkage of "Private" and "Public" Corporate Codes of Conduct, 18 IND. J. Global LEGAL STUD. (2011).

88. Christian Bühring-Uhle, Horst Eidenmüller \& ANDREas Nelle, VERHANDLUNGSMANAGEMENT 26-30, 67-70 (2009) (Ger.). 
alternatives, TNCs can, all the more by concerted action, wield strong influence on regulators and policy makers (e.g., with regard to WTO negotiations or the enactment of investment treaties). ${ }^{89}$ Internationally operating market actors can pressure national or local representatives by threatening to exit the country in question. ${ }^{90}$ Fearing potential welfare losses for the national economy, politics might be apt to give in to demands with regard to the conclusion of (or consideration of certain provisions in) investment protection agreements, double taxation treaties, and the grant of subsidies, as well as others. This is, once again, especially true for small and mid-sized countries. Taken together, and regardless of how one coins this phenomenon, ${ }^{91}$ this scenario entails the danger of regulatory capture.

In sum, the cost-benefit position of TNCs translates into superior choice incentives. TNCs can choose from an enlarged choice set that comprises private regimes because they are equipped with excellent nonagreement alternatives and, as a consequence, superior bargaining power. Hence, TNCs have stronger incentives, greater opportunities, and more power to engage in legal arbitrage within the transnational law market than small and medium-sized enterprises.

\section{NORMATIVE ASSESSMENT OF THE LAW MARKET}

Normative assessment of the law market and regulatory competition is of central importance for legal policy. This assessment can be made from different perspectives. First, we can ask how law is "produced" in a market environment and how this process is to be evaluated. In addition to this process-oriented perspective, we can also ask how the results and consequences of the law market are to be assessed. This is a results-oriented perspective. Both viewpoints are meaningful and form the basis for the following analysis.

89. See Backer, Multinational Corporations, supra note 71, at 505-08; Karsten Nowrot, Transnational Corporations as Steering Subjects in International Economic Law: Two Competing Visions of the Future? 18 IND. J. GLOBAL LEGAL STUD. _(Part. II.A-B) (2011); see also Behrens, supra note 11 , at 59.

90. See Meessen, supra note 27, at 705.

91. In public international law, the debate revolves around the issue of whether to ascribe "functional statehood" to powerful transnational corporations. For details, see Tillmann Rudolf Braun, Der Staat zieht sich zurück, FRANKFURTER ALLGEMEINE ZEITUNG [FAZ] (Frankfurt), Jan. 30, 2009, http://www.faz.net/-00ml00; Weilert, supra note 68, at 909, 911-12. 


\section{A. Process-Oriented Perspective}

A purely process-oriented perspective makes objections to the law market appear obvious. As already mentioned, we conceive law to be the result of public debate and decisions of elected representatives. We regard it as strange that law should instead be considered a product "made" by the market. Such a scenario would appear to involve corruption of the political process.

Upon closer inspection, however, this objection proves to be unfounded. The law market is a function of legal rules allowing choice of law. Simply put, the law market itself is the product of law. The legal rules permitting these choice opportunities are deliberately set by competent law-making bodies after a reflective process. This applies equally to judge-made case law. Moreover, relevant legislation and judicial decisions affecting choice of law can, at least in principle, be altered. It is therefore possible to second-guess and withdraw previously granted opportunities to choose. Even if a particular country cannot influence the rules of the game or can only do so to a limited extent-in the case of choice opportunities being granted at a supranational level, for instance - it nevertheless, at least in principle, is free to deliberately withstand competitive pressure and align legal policy according to other factors. In other words, no country is forced to fix legal rules purely or predominantly from the point of view of their success on the transnational law market. The law market, therefore, leaves the primacy of politics untouched.

\section{B. Results-Oriented Perspective}

Decisive questions hinge on whether a country should grant opportunities for choice of law and whether it should succumb to competitive pressure and act as a competitor in the law market. The answers to these questions depend on the consequences of regulatory competition and how these consequences are assessed. This suggests a results-oriented perspective.

From a philosophical point of view, a results-oriented perspective does not automatically imply a utilitarian perspective. If, in the Kantian tradition, one assumes that there is good (right) law, independent of the preferences of the persons subject to the law, then this is a nonutilitarian perspective on the consequences of the law market. From this perspective, law as a product is almost automatically fraught with problems.

However, such a non-utilitarian view of the law market does not mean that a utilitarian perspective would be wrong or unhelpful. The 
opposite is true. Considering normative questions of political philosophy, the orientation towards the preferences of those who are affected by certain legal rules obviously has great appeal. Yet, this approach requires a utilitarian (or public welfare economic) assessment of the law market and its consequences. ${ }^{92}$ Such an assessment will be attempted in the following section.

\section{The Law Market as a Discovery Process}

Many decades ago, this issue was at the center of an important decision by the U.S. Supreme Court concerning company law. In a famous dissenting opinion, Justice Brandeis suggested, "Companies were early formed to provide charters for corporations in states where the cost was lowest and the laws least restrictive. The states joined in advertising their wares. The race was one not of diligence but of laxity."93 Brandeis thought that regulatory competition in company law would lead states to lower protective standards-for shareholders, creditors, and others-in order to become or remain attractive. The German Federal Supreme Court voiced similar concerns in its order to refer a case to the European Court of Justice in the Überseering proceedings. The court stated, "It is to be feared that in a competition between legal systems of this sort, precisely the legal system with the weakest protection for third party interests will succeed ('race to the bottom')." 94 Both decisions deal exclusively with the market for company law, but they refer to a general issue of paramount importance: the question of whether the law market and regulatory competition actually promote public welfare as a whole or whether they only benefit individual participants at the expense of the public.

\section{a. Theoretical Considerations}

Something that generally holds for public welfare effects of markets should also hold for the law market. Just as products and services markets generally lead to an efficient equilibrium, provided that certain conditions are fulfilled, the law market should produce such equilibrium

92. This does not fail to recognize that utilitarianism and public welfare economics, as legislative theories, can of course be challenged. See HORST EIDENMÜLLER, EFFIZIENZ ALS RECHTSPRINZIP 173-234 (3d ed. 2005) (Ger.) (presenting utilitarianism and public welfare economics as one, but not the only meaningful one, conceivable and helpful legislative perspective on the law market).

93. Louis K. Liggett Co. v. Lee, 288 U.S. 517, 558-59 (1933).

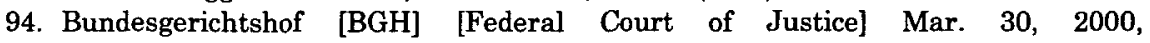
JURISTENZEITUNG [JZ] 903, 904, 2000 (Ger.). 
as well. ${ }^{95}$ Thus, regulatory competition between countries apparently has the potential to initiate a discovery process for the best or most efficient law. ${ }^{96}$ The basic argument is that countries will invent new law products if they assume demand for them, and these law products will establish themselves on the market if the demand is present. Other countries will then imitate the innovative country. The historical emergence and prevalence of the limited liability company in the United States seems to confirm this assessment. ${ }^{97}$

At the same time, regulatory competition between countries can be viewed as a tried and tested means to balance the influence of powerful interest groups within individual jurisdictions. Regulatory competition gives citizens the means to counteract public choice failures in the legislative process in their own country; "bad law" is not chosen. This aspect is important, especially with regard to so-called developing countries. Jurisdictions that do not yet have reliable and transparent rules cannot deny that the development of their country rests on building a solid legal infrastructure. For example, consider the case of dispute resolution: If a country's own judicial system is corrupt, the only and frequent escape is to seek international arbitration.

Finally, regulatory competition involves different legislative units (e.g., countries and jurisdictions) with competing local competences. These local units are able to provide appropriate legislative consideration to differences in local preferences. The fact that regulatory competition is an instrument for limiting the influence of interest groups at a local level does not mean that legislation that is oriented towards local preferences cannot be beneficial. In other words, regulatory competition has the potential for local law to establish itself because it is efficient. ${ }^{98}$

95. For a detailed (and critical) discussion of the theoretical bases of regulatory competition and the necessary conditions for equilibrium, see William W. Bratton \& Joseph A. McCahery, The New Economics of Jurisdictional Competition: Devolutionary Federalism in a Second-Best World, 86 GEO. L.J. 201 (1997).

96. See, e.g., Peer Zumbansen, Spaces and Places: A Systems Theory Approach to Regulatory Competition in European Company Law, 12 EUR. L. J. 534, 550 (2006); cf. Friedrich A. Hayek, Competition as a Discovery Procedure, in NEW STUDIES IN PHILOSOPHY, POLTICS AND THE HISTORY OF IDEAS 179-90 (Friedrich A. Hayek ed., 1978).

97. For a brief description of the history of the limited liability company, see $L L C$ History, LIMITED LIABILITY Co. REP., http://www.llc-reporter.com/16.htm (last visited Mar. 6,2011 ) (citing further references).

98. Bratton \& McCahery, supra note 95, at 213-16, 260-68. 


\section{b. Empirical Findings}

This is the theory. By contrast, empirical evidence as to the beneficial effects of regulatory competition on public welfare is comparatively scarce, often inconclusive, and relates primarily to a specific market segment, namely company law. In this context, so-called event studies from the 1980 s revealed that shareholders of corporations in the United States clearly see reincorporation in Delaware as a positive sign because firms' stock market prices increased..$^{99}$ In the case of reincorporation as an $\mathrm{SE}$, an investigation of the development of the stock market price recently reached a similar result. Reincorporation as an SE was considered a positive sign by shareholders as well. ${ }^{100}$ These event studies show that regulatory competition in company law tends to produce better law, which increases shareholder value. Other results in line with these findings indicate that companies incorporated in Delaware apparently have a higher company value (i.e., Tobin's q) than other companies. 101

On the other hand, it is very difficult from a methodological point of view to exclude self-selection effects in the cited studies. It might be the case that it is not Delaware law that triggers an increase in stock market prices or company value, but instead, that companies that are more valuable in the first place, or plan a transaction that will increase value, seek incorporation in Delaware for completely different reasons. Moreover, the company law of Delaware also contains provisions that make takeovers more difficult. Such provisions are generally considered to be harmful to shareholders. ${ }^{102}$ In any case, Delaware's company law does not appear to be as efficient as it could be, even if the cited provisions do not go as far as those of other states in the United States. Finally, it should not be forgotten that event studies of the type previously cited only measure welfare effects with regard to

99. See Roberta Romano, The Genius of american Corporate law 20 (1993) (referencing a number of these studies).

100. See Horst Eidenmüller, Andreas Engert \& Lars Hornuf, How Does the Market React to the Societas Europaea?, 11 EUR. BUS. ORG. L. REV. [E.B.O.R.] 35 (2010) (finding positive, albeit not statistically significant, effects).

101. See Robert M. Daines, Does Delaware Law Improve Firm Value?, 62 J. Fin. Econ. 525, 525-58 (2001). But see Guhan Subramanian, The Disappearing Delaware Effect, 20 J.L. ECON. \& ORG. 32 (2004) (finding that although Delaware corporations were worth more than non-Delaware corporations from 1991-1996, they are not worth significantly more after 1996).

102. See Lucian Arye Bebchuk \& Alma Cohen, Firms' Decisions Where to Incorporate, 46 J.L. \& ECON. 383, 404-09 (2003); Lucian Bebchuk et al., Does the Evidence Favor State Competition in Corporate Law?, 90 CAL. L. REv. 1775, 1800-06 (2002). 
shareholders. Such studies do not take into account the effects on other stakeholders, such as creditors.

A similarly inconclusive picture emerges with respect to regulatory competition in company insolvency law. Delaware had been the preferred bankruptcy venue in the United States until the end of the twentieth century, when New York took over. Firms reorganized in Delaware show higher refiling rates than firms reorganized elsewhere (which is bad), ${ }^{103}$ but Delaware proceedings are faster than other proceedings (which is good). ${ }^{104}$ Hence, the available empirical evidence with respect to the efficiency effects of bankruptcy forum shopping is mixed.

On the whole, existing empirical studies on the results of regulatory competition hardly serve as a basis for sound conclusions on its positive or negative effects on societal welfare. However, as long as empirical data does not point to clear market failure of regulatory competition in certain market segments, the assumption that regulatory competition produces positive effects as a discovery procedure in the market and for society is a legal policy attitude worth defending. Legal reforms in various jurisdictions specified above certainly offer sufficient evidence that regulatory competition triggers a boost in innovation between competing states. Consequently, problems will probably not lie in the freedom to choose the applicable law and the resulting law market in principle. Rather, they are likely to appear in special situations in which a choice of law is problematic and should not be permitted, or at least should be restricted. This involves cases in which unrestricted choice of law would clearly have negative welfare effects. Some of these fact patterns will be discussed below.

It should be noted at the outset that such negative welfare effects will be examined with respect to the market for legal products and regulatory competition in this market, not with respect to the market for investments and regulatory competition in this field. As is well known, competition for investments might compromise the provision of certain public goods, as private actors do not have sufficient incentives to pay for all public goods (e.g., human rights, environmental protection,

103. See Lynn M. LoPucki \& Sara D. Kalin, The Failure of Public Company Bankruptcies in Delaware and New York: Empirical Evidence of a "Race to the Bottom", 54 VAND. L. REV. 231 (2001); Lynn M. LoPucki \& Joseph W. Doherty, Why Are Delaware and New York Bankruptcy Reorganizations Failing?, 55 VAND. L. REV. 1933 (2002).

104. See Kenneth M. Ayotte \& David A. Skeel, Why Do Distressed Companies Choose Delaware? An Empirical Analysis of Venue Choice in Bankruptcy 15-17 (Univ. of Pa., Inst. for Law \& Econ. Research Paper No. 03-29, 2004), available at http://ssrn.com/ abstract=463001; Robert K. Rasmussen \& Randall S. Thomas, Whither the Race? A Comment on the Effects of the Delawarization of Corporate Reorganizations, 54 VAND. L. REV. 283, 295-297 (2001). 
and labor standards). ${ }^{105}$ However, the market for legal products is a function of the freedom to choose applicable law, irrespective of particular investment decisions. Hence, the problems related to this freedom and the associated market are special.

\section{Freedom of Choice of Law and Third Party Interests}

The first problematic scenario is found where free choice of law would have disadvantageous effects on third parties who are not, or not automatically, in a position to influence this choice and protect their interests. ${ }^{106}$ Economists would say that these are cases in which choice of law triggers negative external effects. Such effects lead to inefficiencies if they cannot be corrected at low transaction cost by negotiations in the markets. ${ }^{107}$

First, the type of third-party affected is important. To the extent that a choice of applicable company law is involved, tort creditors are unable to protect themselves. They are "involuntary creditors." The same applies to so-called "nonadjusting creditors" (e.g., small claims creditors and employees). ${ }^{108}$ Their opportunities to protect themselves are restricted for two reasons. First, it is usually not worth the time, effort, and expenditure required of these creditors to obtain extensive security against an increased credit risk. However, the primary reason such creditors are restricted is because they are normally unable to assert their interests in negotiations effectively due to their weak negotiating position, which stems from their lack of good alternatives in case of failure to reach agreement. ${ }^{109}$ The situation is different with regard to powerful contract creditors, such as banks. In light of these considerations, law-making bodies are justified in providing mandatory protection for tort and other nonadjusting creditors against the consequences stemming from corporations' freedom to choose which laws apply to their business dealings. ${ }^{110}$

105. See MUCHLINSKI, supra note 83, at 463-506, 507-36, 537-74; Weilert, supra note 91 , at 915 .

106. See Rühl, supra note 7, at 178-80.

107. See R.H. Coase, The Problem of Social Cost, 3 J.L. \& ECON. 1, 5-8 (1960).

108. The concept of non-adjusting creditors was introduced by Lucian A. Bebchuk \& Jesse M. Fried, The Uneasy Case for the Priority of Secured Claims in Bankruptcy, 105 YALE L.J. 857, 882-91 (1996).

109. For a discussion of the importance of non-agreement alternatives for one's own negotiation position, see BüHRING-UHLE, EIDENMÜLLER \& NELLE, supra note 88.

110. In the European context, this is - to a certain extent - possible because the freedom of establishment for companies (Articles 49, 54 TFEU) can, according to the case law of the ECJ, be restricted on account of imperative public interest requirements. See 
A second major factor that may negatively impact third-party interests is the timing of choice of law. This is particularly relevant with regard to the freedom to choose applicable insolvency law. If a company is formed, then, in keeping with the analysis, at least larger creditors have some time to react to an altered risk situation associated with the addition of new clauses. However, if the COMI of a company is shifted to a new jurisdiction just prior to an insolvency petition being filed, this is almost certainly an insufficient amount of time for a creditor to react. The situation may be different if the shift of the COMI is steered by certain major creditors. Ultimately, this means that mandatory protective rules, at least in favor of nonadjusting creditors, may be justified with respect to forum shopping immediately prior to business insolvencies. The exception would be creditors who have been active in promoting this forum shopping or who are otherwise responsible for it. 111

\section{Freedom of Choice of Law and Rational Disinterest}

Other problems with choice of law and the market for law products arise when one partner is formally involved in the exercise of choice of law, but actually makes no, or insufficient, use of the legal power granted thereby. The problem of such "rational apathy" particularly arises in connection with standard terms. The opponent of such clauses bases his business decision on the price and quality of a product or service, but not on the quality of the small print. It tends not to be worthwhile for the opponent to study the relevant clauses and then link his decision to enter into a contract to legal regulations, which may or may not exist. In turn, this preference by the nondrafting party has an effect on the conduct of the clause provider; "good quality" (i.e., clauses that grant the opponents far-reaching rights) is not honored by the market, which may result in a deterioration of average "term quality" (i.e., adverse selection) and possibly even a collapse of the relevant market. ${ }^{112}$

HoRST EIDENMÜLLER ET AL., AUSLÄNDISCHE KAPITALGESELLSCHAFTEN IM DEUTSCHEN RECHT § 3 ๆ $20-72$ (Horst Eidenmüller ed., 2004) (Ger.) (citing further references).

111. The provisions of the European Insolvency Regulation on secondary and territorial insolvency proceedings in the Member States in which the debtor maintains a branch can be understood to be such mandatory protective provisions. Council Regulation 1346/2000, arts. 3(2), 27-38, 2000 O.J. (L 160) 5, 9-11 (EC). The manipulation of the COMI is easier than the manipulation of a "physically present" branch.

112. George A. Akerlof, The Market for "Lemons": Quality Uncertainty and the Market Mechanism, 84 Q.J. ECON. 488 (1970) (developing a path-breaking theory on the effects of "good quality" products and services and "lemons" in the underdeveloped world). 
This problem arises not only in connection with standard terms, but also generally where one party to a contract, in contrast to others, has no rational interest in negotiating certain clauses. In the context of choice of law provisions, this applies particularly when consumers are involved.113 A large company with worldwide sales of its products has every incentive to identify the law most favorable to it, and to assert that law into its contracts through choice of law provisions. In view of the large number of contracts entered into, this investment is worthwhile. For the consumer on the other side, however, the opposite is true. Market forces-in particular, reputational effects-act as a correction to the systematic exploitation of consumers by the choice of legal systems in which their interests are not, or not sufficiently, protected. However, this market correction has only limited effect if a company is close to insolvency and has little to lose.

In the example of bond covenants discussed above, this can be the basis for justifying why bond covenants that restrict creditors' rights should be controlled and why such control should be possible. In principle, this also applies to choice of law clauses contained in such bond conditions. However, if one were to consider such clauses null and void in cases where appropriate (i.e., vis-à-vis certain individuals or institutions), the bond might then be subject to different legal systems. This would destroy the uniform treatment of the issue. For this reason, article 6(4)(d) of the Rome I Regulation ${ }^{114}$ ultimately and rightly provides that the freedom of parties to insert such choice of law clauses should be upheld by the judiciary. ${ }^{115}$

There is no substantive basis for courts to void choice of law clauses where, for example, two companies subject a large-scale contract to foreign law, such as Swiss law, following protracted negotiations. Where the companies involved are highly sophisticated, it must be assumed that all participants know what they are doing. The same applies to substantive contractual conditions contained in such clauses. The case law of the German Federal Supreme Court, which generally classifies such clauses as standard terms and reviews them according to clause review standards, is therefore rightly criticized. ${ }^{116}$

113. See Rühl, supra note 8 , at $180-82$.

114. Council Regulation 593/2008, on the Law Applicable to Contractual Relationships Under the Law of Obligations (Rome I), 2008 O.J. (L 177) 6, 12 (EC).

115. For a detailed analysis, see Peter Mankowski, Finanzverträge und das neue Internationale Verbrauchervertragsrecht des Art. 6 Rom I-VO, RECHT DER INTERNATIONALEN WIRTSCHAFT [RIW] 98-118 (2009) (Ger.).

116. See supra Part III.B. 


\section{Freedom of Choice of Law and Irrational Conduct}

The two possible reasons discussed above, which promote restrictions on the freedom of parties to insert choice of law provisions in contracts, even when the contracting parties are acting rationally, concern the economically inefficient results that are to be expected from such behavior. Such inefficient results may be seen with regard to the negative effects that such provisions have on third parties, or, where a party to the contract has no interest in a choice of law provision or finds it insufficiently valuable when weighed against the other benefits associated with entering into the agreement.

In the last three decades, social science research has shown that under certain circumstances, individuals act irrationally, not only occasionally, but virtually systematically. ${ }^{117}$ This applies, for instance, to people's optimistic yet unjustified assessments ("over-optimism"), to their underestimation of future losses or profits ("hyperbolic discounting"), to their overvaluation of things in their possession (when compared to things which they do not have-"endowment effects"). Some of these phenomena are relevant in the context of regulatory competition and the law market as well. Consider the following: German founders of companies who see the direct advantages of an English Ltd. (e.g., swift and cost-effective formation), but underestimate the consequential costs associated with it (e.g., expert advice).

Nevertheless, it is sound policy not to take these considerations as grounds for limiting the freedom of choice of law. First, these considerations are not specific with regard to the choice of foreign law, but rather generally relevant for the composition of substantive law on a national level. If one considers a specific phenomenon of irrationality to be empirically demonstrated-which may well be disputed-, the appropriate policy reaction is a review of the general legal reaction by the competent authority to this phenomenon. There is no reason to restrict such review to parties' decisions about the choice of law. Instead, a review of national substantive law would be appropriate. Second, care should be taken when considering such legal reactions. The appropriate legislative answer to systematic irrationalities is in no way obvious. Should the private parties' freedom to make decisions be limited as a whole? Or, should the legal system work towards rational decisions ("debiasing through law"118)? Does it perhaps even make sense

117. See, e.g., Horst Eidenmüller, Der homo oeconomicus und das Schuldrecht: Herausforderungen durch Behavioral Law and Economics, JURISTENZEITUNG [JZ] 216, 218.19 (2005) (Ger.) (including further references).

118. See generally Christine Jolls \& Cass R. Sunstein, Debiasing Through Law, $35 \mathrm{~J}$. LEGAL STUD. 199 (2006) (discussing how “debiasing through law . . . could work to address 
to maintain counterfactually the assumption of rational behavior? If the consequences of irrational behavior are bearable in an individual caseas is usual where pecuniary loss is concerned-, then there is much to be said in favor of this last-mentioned legislative strategy. It is not advisable for a legal system dedicated to private autonomy to prevent or protect every person entering into a contract from every mistake, even mistakes that may have high costs to the contracting parties. This reasoning also has an economically sensible and educational effect on the public.

\section{Freedom of Choice of Law and Unbundling}

As touched upon earlier, expanded opportunities for freedom to choose applicable law imply that an "unbundling" of issues becomes easier. Market actors can be sector-specific in their choices (i.e., they are not forced to accept or reject the laws of a particular country en bloc). This kind of "cherry-picking" is bound to lead to inefficiencies where legal institutions that complement each other are unbundled.119 Consider, for example, the following hypothetical: a specific issue of creditor protection, namely the ranking of shareholder loans in a company's insolvency proceedings. Jurisdiction A subordinates such claims in its company law, while Jurisdiction B subordinates such claims in its company insolvency law. Let us assume that the company's owners are based in A. They use a company law form from Jurisdiction $B$ for the business, and, upon financial failure, they put the company into insolvency in A. It appears that they have the best of both worlds, at least with respect to shareholder loans. However, restricting the shareholders' choice is clearly warranted in such a scenario. ${ }^{120}$

\section{Freedom of Choice of Law and Path Dependencies}

Finally, due to path dependencies, the law market and the associated competition between jurisdictions may not necessarily lead to an efficient outcome. National laws are the emanation of social systems

legal questions across a range of areas, from consumer safety law to corporate law to property law" and "steer people in more rational directions").

119. See Behrens, supra note 11, at 54-55; Klaus Heine \& Wolfgang Kerber, European Corporate Laws, Regulatory Competition and Path Dependence, 13 EUR. J.L. \& EcoN. 47, 60 (2002) (including further references); Wolfgang Schön, Playing Different Games? Regulatory Competition in Tax and Company Law Compared, 42 C.M.L. REv. 331, 353-57, 359-60, 364 (2005).

120. EIDENMÜLLER ET AL., supra note $110, \S 9$ ๆ 44. 
and legal traditions having developed over the time.121 These developments have created historically determinated lock-in effects. ${ }^{122}$ To exemplify this, replacing a certain set of rules (e.g., the corporate charter) by another can cause significant transaction costs triggered by, inter alia, uncertainty as to the efficiency and effects of the new rules or information costs with regard to external advice on the new regime. ${ }^{123}$ Also, the existing set of laws may be adjusted in accordance with other rules of the same legal system (e.g., "complementaries"), and there may exist dynamic scale economies associated with its use. This happens, for example, when professionals are trained to apply and work with certain rules. Hence, a switch to a new legal regime may not take place, even though, in principle, the change in law would be more efficient. Due to distinct differences among legal systems, path dependencies may be more prominent in EU Member States than in the United States. ${ }^{124}$

However, it should be noted that path dependencies are not an argument against allowing choice of law or against the associated market for legal rules. Path dependencies indicate that the law market and regulatory competition between jurisdictions is not going to lead to the most efficient regime being adopted by all jurisdictions. In other words, they point to the limits of the competitive pressure being exerted by the market for legal rules. Curtailing options for choice is not a policy conclusion that one should derive from this assessment.

In sum, the transnational law market has the potential to bring about a discovery procedure for innovative and efficient legal products in all of its segments. Problems may arise in some distinct situations where allowing free choice of the applicable law cannot be assumed to have such beneficial effects. Specifically, justification for curtailing the law market may be seen if third parties are harmed by such choice, if at least one of the choosing parties has no rational interest in the outcome of the choice, or if the choice involves cherry-picking, which unbundles complementaries in a particular legal system.

121. See Heine \& Kerber, supra note 119, at 53-54, 63-64 (regarding German company law); Zumbansen, supra note 96 , at 534-535.

122. See Behrens, supra note 11, at 55-56; Heine \& Kerber, supra note 119, at 53-60. See generally Lucian A. Bebchuk \& Mark J. Roe, A Theory of Path Dependence in Corporate Ownership and Governance, 52 STAN. L. REv. 127 (1999) (discussing how an economy's initial corporate ownership structure can lead to inefficient path dependencies).

123. See Heine \& Kerber, supra note 119, at 59-60 (including further references).

124. See Vahagn Movsesyan, Regulatory Competition Puzzle: The European Design 33 (Lab. of Econ. \& Mgmt., LEM Papers Series No. 2006/30, 2006), http://papers.ssm.com/sol3/papers.cfm?abstract_id=985319. 


\section{POLICY RECOMMENDATIONS FOR THE LAW MARKET}

These considerations may serve as a basis for an answer to the question as to how the law market should be regulated. As a starting point, one must remember that the law market and, thus, regulatory competition is a function of the law. The existing governance framework is therefore important. It defines conditions under which regulatory competition between individual countries emerges and establishes selection constraints for successful and less successful law products. ${ }^{25}$ The focus in the following segment of this article is the European legal governance structure, which poses special and intriguing problems for a federal legal system. However, the policy principles developed for this system should, mutatis mutandis, also be helpful in designing appropriate framework conditions elsewhere. Further, the question will be asked whether a special regulatory regime is warranted vis-à-vis transnational corporations.

\section{A. The European Union}

\section{Guaranteeing Regulatory Competition}

If one assumes that regulatory competition between the Member States is welcomed because it leads to positive results for society (e.g., increased social welfare), the European Union should guarantee this competition by legislation on opportunities for choice of law. These opportunities should be granted at the supranational European level. It is not sufficient for some or all individual Member States to adopt a correspondingly liberal attitude. Each Member State could then decide for itself to partly withdraw from regulatory competition by the abolition of choice opportunities. For example, the European Court of Justice (ECJ) rightly decided to ensure Europe-wide recognition of the incorporation theory in international company law in its Centros case law.

However, one may ask whether the fundamental framework conditions of regulatory competition at the European level should not be established by statutory law rather than by rules formed through case law. An increase in legal certainty would be one of the main advantages. For example, irrespective of the ECJ's welcome case law regarding the recognition of foreign companies, a European regulation on

125. See Viktor J. Vanberg \& Wolfgang Kerber, Institutional Competition Among Jurisdictions: An Evolutionary Approach, 5 Const. PoL. ECON. 193, 210-12 (1994) (outlining "an evolutionary approach to the process of competition among institutions"). 
international company law as a clear legal framework would be helpful. An expert committee set up by the German government has made a corresponding recommendation. ${ }^{126}$

\section{Limiting Regulatory Competition}

Just as the European Union should guarantee regulatory competition, it should also be careful to set necessary limits. Constraints are justified where regulatory competition presumably leads to inefficiencies. Appropriate limitations, as previously noted, should be put into place: (1) to ensure the safeguard of third parties, (2) to overcome inefficiencies associated with rationally apathetic parties, and (3) to combat the unbundling problem. Intervention at the European level should target the market failure in question.

At present, several EU directives on company law have already addressed choice of law issues related to the protection of creditors. Various other legislative projects should be pursued in this context. One example is uniform provisions on management duties in a company crisis that threatens the company's existence. ${ }^{127}$ Such duties would work toward protecting nonadjusting creditors in particular, and they could not be avoided by strategic company law and bankruptcy forum choices.

Further, uniform rules on consumer protection make sense to protect consumers from careless choices of law and counteract information asymmetries. Freedom of choice of law should therefore be recognized in principle (as is the starting-point of article 6(2) clause 1 of the Rome I Regulation). However, the European Union should use mandatory substantive rules to ensure that certain minimum protection standards are maintained. Some mandatory rules, of course, exist already, and new ones are currently being discussed. This applies in particular to the consolidated Consumer Law Directive, a draft of which has recently been proposed. ${ }^{128}$ Certainly, the more extensive such

126. See Proposal of the DeUtscher Rat fÜr Internationales Privatrecht for EUROPEAN AND NATIONAL LEGISLATION IN THE FIELD OF INTERNATIONAL COMPANY LAW 65-122 (Hans Jürgen Sonnenberger \& Frank Bauer eds.,2007).

127. See Communication from the Commission to the Council and the European Parliament, Modernising Company Law and Enhancing Corporate Governance in the European Union - A Plan to Move Forward, at 10-17, COM (2003) 284 (May 21, 2003), available at http:/leurlex.europa.eu/LexUriServ/LexUriServ.do?uri=COM:2003:0284:FIN:EN:PDF. However, following the revision of the Action Plan, this project is (unfortunately) not currently being pursued any further.

128. See Commission of the European Communities, Proposal for a Directive of the European Parliament and of the Council on Consumer Rights, COM (2008) 614 (Oct. 8, 2008), available 
protective provisions are at the European level, the more difficult it is to legitimize consumer protection in conflict of laws, at least where the choice of law of another Member State is concerned. ${ }^{129}$

Regulatory intervention should not go further than necessary, however. ${ }^{130}$ Tools that can be put to use are, inter alia, minimum harmonization and a "menu approach."131 Under the latter approach, Member States retain regulatory options, and private actors have a menu of regimes from which to choose. A role model for such an approach may be found in the optional arrangements provided for Member States and companies by article 12 of the European Takeover Directive. ${ }^{132}$ However, self-regulation will often not be effective. The recent financial crisis particularly provides ample evidence of how selfregulation in the financial sector has failed dismally. ${ }^{133}$

\section{Enriching Regulatory Competition}

Finally, a third important task for the European Union is to enrich regulatory competition by its own law products. Horizontal competition between the Member States would then be complemented by vertical competition between them and legal regulations of the European Union. ${ }^{134}$ In certain areas, this has already taken place. The Societas

http://ec.europa.eu/consumers/rights/docs/COMM_PDF_COM_2008_0614_F_EN_PROPOS ITION_DE_DIRECTIVE.pdf (last visited Mar. 6, 2011).

129. Therefore, Article 6(2) Clause 2 in conjunction with Article 6(1) Rome I Regulation must be critically assessed. According to this provision, the choice of law may not "have the result of depriving the consumer of the protection afforded to him by provisions that cannot be derogated from by agreement by virtue of the law which, in the absence of choice, would have been applicable on the basis of paragraph 1 [law at the consumer's place of habitual residence]." The mandatory protective law of the place of the habitual residence therefore also applies if it is not based on harmonized European law. The application of Article 9 (overriding mandatory provisions) or Article 21 (public policy of the forum) to restrict a choice of law in relation to the Member States also presents problems. Rome I, supra note 114, at 11-12.

130. See Behrens, supra note 11, at 58-59; Simon Deakin, Legal Diversity and Regulatory Competition: Which Model for Europe?, 12 EUR. L. 440, 452 (2006).

131. See Karl M. Meessen, Economic Law as an Economic Good: Its Rule Function and Its Tool Function in the Competition of Systems, in ECONOMIC LAW AS AN ECONOMIC GOOD 3, 19 (Karl Meessen et al. eds., 2009) (regarding minimum harmonization); Roberta Romano, Empowering Investors: A Market Approach to Securities Regulation, 107 YALE L.J. 2359, 2361-62 (1998) (regarding a "menu approach").

132. Council Directive 2004/25, Takeover Bids, 2005 O.J. (L 142) 12, 21 (EC).

133. See John C. Coffee, What Went Wrong? An Initial Inquiry into the Causes of the 2008 Financial Crisis, 9 J.C.L.S. 1 (2009), for more detail.

134. As to competition among rules at different levels, see Buxbaum, supra note 16 , at 13-23. See also Stephen Woolcock, Competition Among Rules in the Single European Market, in INTERNATIONAL REgULATORY COMPETITION AND COORDINATION: PERSPECTIVES 
Europaea (SE), for example, is a product of European law, at least in its core structure, which competes with the Member States' law products for public corporations. It is also likely that the EU will soon establish a new corporate entity, the European Private Company (SPE), which would then compete with national closed corporation entities found in the different Member States. ${ }^{135}$ The same is conceivable in the field of private law. The development prompted by the Common Frame of Reference may result in an optional European Code of Civil Law, which parties may choose..$^{136}$

There is little to be said against the enrichment of horizontal regulatory competition by vertical competition on the part of the European Union. Of course, developing European law products costs money. However, in many fields these costs have already been sunk. For example, this is true in the case of the Societas Europaea (SE) and European civil law. With regard to the latter, numerous research groups were extensively supported over several years to prepare relevant model regulations. ${ }^{137}$ In addition, it is practically impossible to precisely ascertain the benefits of European law products (i.e., uniform law or uniform law products for various cross-border activities), which could more than compensate for the costs incurred. In any case, the evidence on likely cost-benefit effects does not suggest that it would be irresponsible to pursue the project of vertical regulatory competition.

If and to the extent to which, the European Union decides to develop its own law products, these should reflect "best market standards" and be a benchmark for the Member States, instead of containing particularly creative and innovative solutions. It is difficult to reach a consensus at the European level about the structure of certain law products. It is equally difficult to review a consensus that has been reached. At the national level of Member States, both are easier. This argues in favor of Member States primarily carrying out and developing creative solutions. The European level is where established market

ON ECONOMIC REGULATION IN EUROPE AND THE UNITED STATES 287-321 (William Bratton et al. eds., 1996).

135. See supra Part III.A.2.

136. See European Commission, Green Paper on Policy Options for Progress Towards a European Contract Law for Consumers and Businesses, COM (2010) 348 (July 1, 2010), available at http://eurlex.europa.eu/LexUriServ/LexUriServ.do?uri=COM:2010:0348:FIN:en:PDF; see also Christian von BaR et al., Principles, Definitions and Model Rules of EuRopean Private LaW: Draft Common Frame of Reference (DCFR) 80 (outline ed. 2009). As to the DCFR in general, see Horst Eidenmüller et al., The Common Frame of Reference for European Private Law: Policy Choices and Codification Problems, 28 OXFORD J. LEG. STUD. 659-708 (2008).

137. See Eidenmüller et al., supra note 136 , at 665. 
standards should be reflected (i.e., in the sense of presumptively efficient solutions).

\section{B. Member States}

If and to the extent to which the European Union enables and guarantees regulatory competition in different areas, the Member States should make their own law more competitive in these fields. Their primary task is to develop law products that suit their users' interests and are more likely to be selected. At the same time, Member States can ease competitive pressure against their own laws by making their legal rules optional as opposed to mandatory. As previously noted, responsibility for imposing sensible restrictions on regulatory competition lies primarily with the European Union, not the Member States.

Even if the European Union leaves such competence and responsibility to the Member States, ${ }^{138}$ the latter should restrict regulatory competition only if the negative effects of an unrestricted choice of law in a specific situation are obvious. Such obvious negative effects may be found especially vis-à-vis non-Member States. If and to the extent the European Union does not pass any binding provisions in this context, the Member States must decide whether they wish to permit choice of law and open regulatory competition. To permit choice of law presupposes a certain confidence in the protection of third parties or parties with little business experience by those countries whose law may be declared applicable. If this confidence does not exist or cannot be created, restrictions on choice of law opportunities may be justified.

\section{A Special Regulatory Regime for Transnational Corporations?}

Considering the peculiarities of TNCs as powerful actors in the transnational market for legal rules, special consideration should be given to the question of whether these peculiarities require special regulatory tools or distinct legal doctrines to deal with the challenges posed. On its face, the superior choice incentives for TNCs, their enlarged choice set, and their superior bargaining power seem to justify some special regulatory regime.

However, the currently discussed proposals for such a special regime go in very different directions. One suggestion is to subject TNCs

138. The legislative competence of the Union to set conflict of laws rules is beyond doubt. See Consolidated Version of the Treaty on the Functioning of the European Union arts. 81(1), (2)(c) 2008 O.J. (C 115) 47, 78. 
to public international law. ${ }^{139}$ Proponents of this suggestion argue that partial public international legal status should be conferred upon TNCs. They point to recent trends according to which multinational enterprises have been assigned rights under investment protection agreements. Sometimes TNCs even enter into such agreements directly with the host country. ${ }^{140}$ Another proposal is for the development. of distinct, new private law doctrines, specifically designed for TNCs. For example, such doctrines aim at treating TNCs as one single legal unit for liability purposes; concepts such as "network responsibility," "connected contracts," and the "enterprise entity theory" fall into this category. ${ }^{141}$ Another proposal goes so far as to suggest that TNCs should be resocialized and brought again under state ownership on a significant scale to do away with the problems they create in the private law sphere. ${ }^{142}$

Surely, the last suggestion is neither appropriate as a regulatory approach in a market economy framework, nor would it be practical as a general policy. However, the other proposed policy suggestions are also problematic. Subjecting TNCs to public international law would create delicate line-drawing problems. As already discussed, the term "transnational corporation" is elusive in nature. Therefore, legal rules ought not to be tied to the term itself. It seems almost impossible to provide a legal definition of TNCs that is both precise and "justified" in the sense of being neither over-nor underinclusive with respect to the application of certain public international legal rules. Further, it is far from clear why the existing regulatory instruments of national, supranational, and federal laws, such as antitrust, and mandatory contract rules, should not be sufficient or even more appropriate to regulate private, albeit powerful, actors like TNCs.

139. See, e.g., Karsten Nowrot, Reconceptualising International Legal Personality of Influential Non-State Actors: Towards a Rebuttable Presumption of Normative Responsibilities, in INTERNATIONAL LEGAL PERSONALITY 369 (Fleur E. Johns ed., 2010).

140. See Nowrot, supra note 89, [Part III.A]. See also supra note 75 and accompanying text.

141. For an overview, see Backer, Global Private Law Making, supra note 85, at 174445. See also MUCHLINSKI, supra note 83, at 322-35 (regarding group liability); Günther Teubner, Coincidentia Oppositorum: Hybrid Networks Beyond Contract and Organization, in Contractual Networks: Legal Issues of Multilateral COOPERATION 3-30 (Marc Amstutz \& Günther Teubner eds., 2009), available at http://ssrn.com/abstract $=876939$ (regarding hybrid networks and connected contracts). More generally as to the concept of "connected contracts," see G. Mitu Gulati et al., Connected Contracts, 47 UCLA L. REV. $887(2000)$.

142. See Peter T. Muchlinski, The Changing Face of Transnational Business Governance: Private Corporate Law Liability and Accountability of Transnational Groups in a Post-Financial Crisis World Part III, 18 IND. J. GLOBAL LeGaL STUD._(2011). 
Similar problems beset the suggestion to develop specific private law doctrines designed only or at least primarily for TNCs. With respect to concepts that aim at treating TNCs as one single legal entity, it should be noted that the economic benefits of keeping separate legal entities separate should not be sacrificed too quickly. The proposed concepts also, thus far, lack precision. Hence, the focus should be on transnational regulation rather than on transnational liability under private law. Pertinent approaches to subject matters that can only be tackled sensibly at an international level are, to name just a few, the OECD Guidelines for Multinational Enterprises and the U.N. Global Compact initiative. ${ }^{143}$ Common characteristics of these guidelines and initiatives are the principle of voluntary submission and their public sector origin. If voluntary submission is not deemed to be an appropriate tool, a set of harmonized rules should be carved out at the international level that, in a second step, are then to be translated into standards recognized and enacted by the national legislatures (e.g., G20 or the Basle Committee on Banking Supervision).

In sum, "traditional" regulatory instruments and the existing governance framework of national, supranational, and federal laws provide appropriate regulatory tools for TNCs. A special regulatory regime for TNCs is not warranted.

\section{SUMMARY}

Over the years, a transnational law market has emerged. Law has become a product-in many parts of the world and in relation to numerous different subjects. Individuals and companies seek attractive legal rules, and countries compete for customers of their legal wares. Transnational corporations are important actors in the markets for investments and legal products. Nevertheless, they are not the only active market participants. Small and medium-sized enterprises and individuals compete for legal products as well. The main conclusions of this article can be summarized as follows:

1. The development of the law market is based upon fundamental changes in the framework conditions on the demand side, as well as on the supply side for legal rules. On the demand side, it is, above all, the expanded opportunities for choice of law in the conflict of laws regulations enacted in many countries. This expansion of choice of law opportunities has greatly increased the options for legal arbitrage. In

143. For more information, see http://www.unglobalcompact.org/ and http://www.oecd.org/department/0,3355, en_2649_34889_1_1_1_1_1,00.html, respectively (last visited Aug. 3, 2010). See also Weilert, supra note 68, at 913-14. 
addition, technological developments have facilitated swift and informed choices of law. On the supply side, countries do compete for investments (as they have done for a long time), but an increasing number of them have also started to actively market their law products and to facilitate the choice by private actors. In particular, this is attributable to the economic advantages arising for countries if their law is successful in international markets.

2. Regulatory competitions and the marketing of law products have developed into a universal phenomenon. For Europe, as for the United States, examples of this can be found in company law, contract law, the law of dispute resolution, and insolvency law. In all of these market segments, Anglo-American legal concepts are particularly popular and gradually displace those of continental Europe. German law is often regarded as inflexible and unfriendly to entrepreneurs.

3. The law market brings fundamental changes to basic categories of the polity. The equation between territorial sovereignty of a state and applicable law increasingly fails to add up. The power of a country to pass binding legislation for acts in its territory at least decreases if choice opportunities are granted at a supranational level.

4. The law market does not threaten the political process. Instead, the origin and expansion of the law market may be seen as a consequence of legal rules that were deliberately enacted following public debate. The law market is a product of law. The primacy of politics is preserved.

5. Regulatory competition between the legal products of different states and the law market are, in principle, to be assessed positively and used as a process to discover which law is best. Hence, regulatory competition is tenable as a policy choice. Existing empirical findings do not indicate systematic market failure, which would automatically lead to a skeptical view of the law market.

6. However, constraints on regulatory competition are justified where they presumably leads to inefficiencies. Free choice of law in a law market is problematic if the interests of uninvolved third parties are negatively affected. Choice of law provisions also lead to inefficiencies where one participant formally enjoys free choice, but actually has no interest in its exercise and is thus rationally apathetic in relation to the choice. Further, cherry-picking by market actors and an unbundling of complementary legal rules should be counteracted. In all these cases, the law must restrict opportunities for a choice of law by suitable framework conditions and ought to target the market failure in question. Intervention should not go further than necessary, preserving leeway for parties and law-making bodies to experiment and choose. 
7. In accordance with the fundamentally positive assessment of regulatory competition and the law market, the European Union should not only permit regulatory competition between Member States, but in principle also guarantee it. The European Union should, however, set binding limits for regulatory competition where it has negative effects and where individual participants make unconsidered, or practically no, decisions as to the choice of legal rules. Finally, there is nothing to be said against the vertical enrichment of horizontal regulatory competition between Member States by the European Union's own law products.

8. Member States should make their legal regimes more competitive where they are subject to regulatory competition at an international level and develop better law products (i.e., make them more efficient). They should restrict opportunities for choice of lawpresupposing they have the necessary legal competence to do so at allonly if the detrimental effects of a choice of law are obvious in an individual case.

9. TNCs are special, but they are not so distinct that they warrant their own, peculiar regulatory regime. Traditional regulatory instruments and the existing governance framework are also suitable for transnational corporations. 
